\title{
Chlorophyll-a patterns and mixing processes in the Yucatan Basin, Caribbean Sea
}

\section{Patrones superficiales de la clorofila a y procesos de mezcla en la cuenca de Yucatán, mar Caribe}

Iván Pérez-Santos ${ }^{1,2 *}$, Wolfgang Schneider ${ }^{1}$, Arnoldo Valle-Levinson ${ }^{3}$, José Garcés-Vargas ${ }^{4}$, Inia Soto ${ }^{5,6}$, Raúl Montoya-Sánchez ${ }^{2}$, Nelson Melo González ${ }^{7}$ Frank Müller-Karger ${ }^{5}$

${ }^{1}$ Departamento de Oceanografía, Universidad de Concepción, Campus Concepción, Víctor Lamas 1290, Casilla 160-C, CP 4070043, Concepción, Chile.

${ }^{2}$ Centro de Investigación Oceanográfica en el Pacifico Sur-Oriental (COPAS Sur Austral), Universidad de Concepción, Campus Concepción, Víctor Lamas 1290, Casilla 160-C, CP 4070043, Concepción, Chile.

${ }^{3}$ Department of Civil and Coastal Engineering, University of Florida, Gainesville, FL 32611, USA.

${ }^{4}$ Instituto de Ciencias Marinas y Limnológicas, Facultad de Ciencias, Universidad Austral de Chile, Edificio Pugín, Campus Isla Teja, Chile.

${ }^{5}$ Institute for Marine Remote Sensing, College of Marine Science, University of South Florida, St. Petersburg, FL 33701, USA.

${ }^{6}$ Laboratório de Estudos dos Oceano e Clima, Universidade Federal do Rio Grande, Rio Grande, Rio Grande do Sul, CEP 96.201-900, Brasil.

${ }^{7}$ Physical Oceanography Division, NOAA/Atlantic Oceanographic and Meteorological Laboratory Rosenstiel School of Marine and Atmospheric Science/Cooperative Institute for Marine and Atmospheric Studies of the University of Miami, 4301 Rickenbacker Causeway Miami, FL 33149-1026, USA.

* Corresponding author. E-mail: ivanperez@udec.cl

\begin{abstract}
Daily images collected with the MODIS sensor on the NASA Aqua satellite were used to describe chlorophyll- $a$ (chl-a) concentrations before, during, and after synoptic-scale meteorological pulses in the Yucatan Basin, Caribbean Sea. The relative influence of vertical diffusive and vertical advective transport on mixing of the near surface layer was quantified with wind data from the QuikSCAT satellite. Computation of vertical density eddy diffusivity and gradient Richardson numbers was done with data from the three-dimensional MERCATOR model. The model evidenced the importance of vertical shear (i.e., vertical diffusive processes) in generating mixing during autumn and winter (2007-2009). During moderate meteorological pulses (e.g., cold fronts, easterly tropical waves, and low-pressure systems with wind speeds of 9-15 $\mathrm{m} \mathrm{s}^{-1}$ sustained over 2 days), mixing caused by diffusive transport (eddy viscosity of $10 \times 10^{-3} \mathrm{~m}^{2} \mathrm{~s}^{-1}$ ) was at least one order of magnitude higher than upward advective mixing $\left(0.3 \times 10^{-3} \mathrm{~m}^{2} \mathrm{~s}^{-1}\right)$. During the passage of hurricanes Ivan (September 2004) and Wilma (October 2005), upward advective mixing $\left(5-7 \mathrm{~m}^{2} \mathrm{~s}^{-1}\right)$ dominated mixing of the upper water column and was nearly four orders of magnitude higher than during moderate meteorological events. Background chl- $a$ concentrations of $0.03-0.08 \mathrm{mg} \mathrm{m}^{-3} \mathrm{were}_{\mathrm{s}}$ observed during the July-October period. During synoptic weather pulses, three different patterns in the chl- $a$ concentrations were observed: first, chl- $a$ concentrations in the range of 0.05 to $0.12 \mathrm{mg} \mathrm{m}^{-3}$ followed moderate meteorological pulses; second, higher regional chl- $a$ concentrations $\left(0.5-2.0 \mathrm{mg} \mathrm{m}^{-3}\right)$ followed the passage of hurricanes; and third, the formation of filaments showing apparent high chl- $a\left(0.3-1.5 \mathrm{mg} \mathrm{m}^{-3}\right)$ south of Cuba, possibly caused by freshwater discharge from land. The changes in chlorophyll patterns following meteorological events illustrate typical patterns of connectivity among different parts of the Yucatan Basin.
\end{abstract}

Key words: satellite chlorophyll- $a$, wind mixing, vertical transport, surface currents, Yucatan Basin.

RESUMEN. Las imágenes diarias del sensor MODIS a bordo del satélite Aqua permitieron identificar los patrones superficiales de la clorofila $a$ antes, durante y después del paso de eventos meteorológicos de escala sinóptica por la cuenca de Yucatán, mar Caribe. Los datos de viento superficial del satélite QuikSCAT se utilizaron para cuantificar la influencia del transporte vertical advectivo y la difusividad vertical en la mezcla de la capa superficial del mar. Los datos del modelo tridimensional MERCATOR permitieron el cálculo de la difusividad vertical de remolino y el número de Richardson, evidenciando la importancia de la cizalladura vertical durante las épocas de otoño e invierno (2007-2009). Durante el paso de eventos sinópticos moderados (e.g., frentes fríos, ondas tropicales del este y sistemas de baja presión con vientos de 9 a $15 \mathrm{~m} \mathrm{~s}^{-1}$ sostenidos durante dos días), la mezcla causada por la difusividad vertical $\left(10 \times 10^{-3} \mathrm{~m}^{2} \mathrm{~s}^{-1}\right)$ fue al menos un orden de magnitud mayor que el transporte vertical advectivo $\left(0.3 \times 10^{-3} \mathrm{~m}^{2} \mathrm{~s}^{-1}\right)$. Sin embargo, durante el paso de los huracanes Iván (septiembre de 2004) y Wilma (octubre de 2005), el transporte vertical advectivo $\left(5-7 \mathrm{~m}^{2} \mathrm{~s}^{-1}\right)$ dominó la mezcla de la columna de agua y fue cuatro órdenes de magnitud mayor al registrado durante la influencia de los eventos moderados. Bajo la influencia de estos eventos meteorológicos, se observaron tres patrones en la clorofila $a$ : en el primero se encontraron concentraciones de clorofila $a$ en el rango de 0.05 a $0.12 \mathrm{mg} \mathrm{m}^{-3}$ 
después del paso de eventos meteorológicos moderados, en el segundo se hallaron máximos de clorofila $a\left(0.5-2.0 \mathrm{mg} \mathrm{m}^{-3}\right)$ después del paso de los huracanes Iván y Wilma, y en el tercero se observó la presencia de concentraciones altas de clorofila $a\left(0.3-1.5 \mathrm{mg} \mathrm{m}^{-3}\right)$ en forma de filamentos debido a las descargas de aguas dulces desde la isla de Cuba. Los cambios en los patrones superficiales de clorofila después del paso de eventos meteorológicos evidenciaron los patrones típicos de conectividad entre las diferentes áreas de la cuenca de Yucatán.

Palabras clave: clorofila a satelital, mezcla por viento, advección vertical, corrientes superficiales, cuenca de Yucatán.

\section{INTRODUCTION}

Satellite-derived chlorophyll- $a$ (chl-a) concentrations, computed based on the ratio of seawater-leaving radiances obtained by ocean color sensors, have been applied to study the temporal and spatial variability of highly productive upwelling systems (e.g., Peláez and McGowan 1986, McClain 2009), as well as the functioning of oligotrophic systems (e.g., Babin et al. 2004). Maximum chl- $a$ concentrations in upwelling systems are reached when the availability of nutrients and solar radiation to phytoplankton are optimal, and grazing is minimal. In oligotrophic regions, high chl- $a$ levels can occur when well-lit surface waters experience a break-down in thermal stratification and increased mixing due to wind, resulting in the availability of nutrients from the subsurface layer (Müller-Karger et al. 1991, González et al. 2000).

By analyzing satellite-derived chl- $a$ from the Coastal Zone Color Scanner (CZCS), Müller-Karger et al. (1991) obtained the first multi-year time series of monthly mean surface chl- $a$ concentrations for the oligotrophic Gulf of Mexico and the northwestern Caribbean Sea; they observed higher Chl- $a$ concentrations from December to February $\left(>0.18 \mathrm{mg} \mathrm{m}^{-3}\right)$ and lower concentrations in May and June $\left(\sim 0.06 \mathrm{mg} \mathrm{m}^{-3}\right)$. The deepening/shoaling of the mixed layer was found to be a major factor controlling chl- $a$ seasonality. González et al. (2000) further examined these patterns of phytoplankton concentrations in the Caribbean Sea, the Gulf of Mexico, and the Sargasso Sea, and discovered that the highest chl- $a$ concentrations were associated with higher vertical mixing after the passage of cold fronts.

Off southwestern Cuba and in the Yucatan Basin, cold fronts from the northwest are frequent from October to April. On average, about 11 to 35 cold fronts affect the area every year, with a historic mean of $19.8 \pm 4.9$ for the winter season (González 1999). In addition, easterly tropical waves occur in the tropical North Atlantic from June to November and can generate hurricanes in the region.

Different studies have characterized chl- $a$ distributions at the seasonal scale in the western Caribbean Sea. In particular, the Yucatan Basin is affected by weather phenomena yearround, including moderate (e.g., cold fronts, easterly tropical waves, low pressure systems) and extreme (hurricanes) meteorological forcing (Pérez-Santos et al. 2010). In this manuscript we describe chl- $a$ distributions in the Yucatan Basin at synoptic scales and assess their response to winds and circulation regime.

\section{INTRODUCCIÓN}

Las concentraciones de clorofila $a$, estimadas con base en la razón de las radiancias emergentes del agua obtenidas por medio de sensores remotos que miden el color del océano, han sido usadas para estudiar la variabilidad temporal y espacial de sistemas de surgencia altamente productivos (e.g., Peláez y McGowan 1986, McClain 2009), así como el funcionamiento de sistemas oligotróficos (e.g., Babin et al. 2004). Las máximas concentraciones de clorofila $a$ en los sistemas de surgencia suceden cuando la disponibilidad de nutrientes y la radiación solar sobre el fitoplancton son óptimas y el pastoreo es mínimo. En regiones oligotróficas, se obtienen altos niveles de clorofila $a$ cuando se rompe la estratificación termal de las aguas superficiales bien iluminadas e incrementa la mezcla debido al viento, con la consecuente disponibilidad de nutrientes de la capa subsuperficial (Müller-Karger et al. 1991, González et al. 2000).

Mediante el análisis de datos obtenidos con el sensor Coastal Zone Color Scanner (CZCS), Müller-Karger et al. (1991) obtuvieron, por primera vez, una serie de tiempo multianual de la concentración media superficial de clorofila $a$ para las aguas oligotróficas del golfo de México y el mar Caribe noroccidental, observándose mayores concentraciones de clorofila $a$ entre diciembre y febrero $\left(>0.18 \mathrm{mg} \mathrm{m}^{-3}\right)$ y menores concentraciones en mayo y junio $\left(\sim 0.06 \mathrm{mg} \mathrm{m}^{-3}\right)$. El hundimiento de la capa de mezcla jugó un papel importante en la estacionalidad de la clorofia $a$. González et al. (2000) examinaron los patrones de las concentraciones de fitoplancton en el mar Caribe, el golfo de México y el mar de los Sargazos, y descubrieron que las mayores concentraciones de clorofila $a$ se asociaban con una mayor mezcla vertical después del paso de frentes fríos.

Al suroeste de Cuba y en la cuenca de Yucatán, los frentes fríos del noroeste son frecuentes de octubre a abril. En promedio, de 11 a 35 frentes fríos afectan el área cada año, con una media histórica de $19.8 \pm 4.9$ para el invierno (González 1999). Además, se presentan ondas tropicales del este en el Atlántico Norte tropical entre junio y noviembre, los cuales pueden generar huracanes en la región.

Distintos estudios han caracterizado la distribución de clorofila $a$ a escala estacional en el mar Caribe occidental. En particular, la cuenca de Yucatán se ve afectada por fenómenos climáticos todo el año, incluyendo forzamientos meteorológicos moderados (e.g., frentes fríos, ondas tropicales del este, sistemas de baja presión) y extremos (huracanes) (Pérez-Santos et al. 2010). En el presente trabajo se describe 
Pérez-Santos et al.: Chlorophyll- $a$ and mixing in the Yucatan Basin

\section{MATERIALS AND METHODS}

\section{Study area}

The study area covers the region between $18^{\circ}$ and $23^{\circ} \mathrm{N}$, and between $80^{\circ}$ and $89^{\circ} \mathrm{W}$ (fig. 1). The region encompasses the Yucatan and Cayman basins, the continental shelf north of the Yucatan Peninsula, and the northern portion of the Mesoamerican Reef System (off the southeastern coast of Mexico and northern Belize).

The Yucatan Basin is located in the area known as the Atlantic warm pool (Wang and Lee 2007), which strengthens during the boreal summer and early autumn. Sea surface temperatures may exceed $28.5^{\circ} \mathrm{C}$, leading to a significant impact on tropical atmospheric convection (Wang and Enfield 2001). The surface wind stress shows a maximum during November as the Atlantic warm pool weakens, and a secondary maximum in June related to the intensification of the Caribbean low-level jet (Pérez-Santos et al. 2010).

\section{Surface wind data from satellites}

Surface wind data obtained from the SeaWinds scatterometer onboard the NASA QuikSCAT satellite were used to calculate wind stress and wind curl. Daily gridded ocean wind vectors with a spatial resolution of $0.5^{\circ} \times 0.5^{\circ}$ were downloaded from IFREMER (Institut Français de Recherche pour l'Exploitation de la Mer). The analysis of satellite wind data covered the period from 21 November 1999 to 21 November 2009.

The Hurricane Research Division (HRD) of the NOAA Atlantic Oceanographic and Meteorological Laboratory (AOML) maintains a high-resolution surface wind speed database (H-Wind product) for particular storm events (http:/ /www.aoml.noaa.gov/hrd). We used this database specifically to examine the passage of hurricanes Ivan (13 September 2004, 0130 UTC) and Wilma (20 October 2005, 1330 UTC) through the Yucatan Basin and because QuikSCAT scatterometers underestimate the magnitude of wind during extreme events (Donelan et al. 2004). The H-Wind product integrates all of the available observations every $6 \mathrm{~h}$ with a spatial resolution of $6 \times 6 \mathrm{~km}$.

\section{MERCATOR assimilation model data}

Results of the three-dimensional MERCATOR assimilation model PSY2V3R1 ATL12 were used to understand the ocean mixing processes (model available at http:// www.mercator-ocean.fr). Since 2007, the daily output of the MERCATOR model is distributed at a spatial resolution of $1 / 12^{\circ}(\sim 9 \times 9 \mathrm{~km})$ and 43 vertical levels. Model output consisting of three-dimensional ocean currents, water temperature, and salinity was extracted from 2007 to 2009 at 36 vertical levels for a domain covering the northwestern Caribbean Sea between $18^{\circ}-21.5^{\circ} \mathrm{N}$ and $80^{\circ}-88^{\circ} \mathrm{W}$. The la distribución de clorofila $a$ en la cuenca de Yucatán a escala sinóptica y se evalúa su respuesta al régimen de circulación y vientos.

\section{MATERIALES Y MÉTODOS}

\section{Área de estudio}

El área de estudio comprende la región entre $18^{\circ}$ y $23^{\circ} \mathrm{N}$ y entre $80^{\circ}$ y $89^{\circ} \mathrm{W}$ (fig. 1). La región incluye las cuencas de Yucatán y Caimán, la plataforma continental al norte de la península de Yucatán y la parte norte del Sistema Arrecifal Mesoamericano (costa sudoriental de México y Belice).

La cuenca de Yucatán se localiza en la zona conocida como la alberca caliente del Atlántico (Wang y Lee 2007), que se fortalece durante el verano boreal y a principios de otoño. La temperatura superficial del mar puede exceder $\operatorname{los} 28.5^{\circ} \mathrm{C}$ y tener un fuerte impacto en la convección atmósferica tropical (Wang y Enfield 2001). El esfuerzo del viento superficial muestra un máximo en noviembre cuando se debilita la alberca caliente del Atlántico y un segundo máximo en julio relacionado con la intensificación del chorro de bajo nivel del Caribe (Pérez-Santos et al. 2010).

\section{Datos satelitales de viento superficial}

Para calcular el esfuerzo del viento y su rotacional, se usaron datos de viento superficial proporcionados por el dispersómetro SeaWinds a bordo del satélite QuikSCAT (NASA). Se obtuvieron vectores diarios del viento en la superficie del mar con una resolución espacial de $0.5^{\circ} \times 0.5^{\circ}$ de IFREMER (Institut Français de Recherche pour 1'Exploitation de la Mer). El análisis de los datos de viento satelitales cubrió el periodo del 21 de noviembre de 1999 al 21 de noviembre de 2009.

La División de Investigación de Huracanes del Laboratorio Oceanográfico y Meteorológico del Atlántico (HRDAOML/NOAA, por sus siglas en inglés) mantiene una base de datos de alta resolución de la velocidad de viento superficial (H-Wind Project) para ciertas tormentas (http:// www.aoml.noaa.gov/hrd). Se usó esta base de datos específicamente para analizar el paso de los huracanes Iván (13 de septiembre de 2004, 0130 UTC) y Wilma (20 de octubre de 2005, 1330 UTC) por la cuenca de Yucatán y porque los dispersómetros de QuikSCAT subestiman la magnitud del viento durante eventos extremos (Donelan et al. 2004). Esta base de datos integra todas las observaciones disponibles cada $6 \mathrm{~h}$ con una resolución espacial de $6 \times 6 \mathrm{~km}$.

\section{Datos del modelo de asimilación MERCATOR}

Para entender los procesos de mezcla en el oceáno, se usaron los datos del modelo tridimensional de asimilación MERCATOR PSY2V3R1 ATL12, disponible en http:// www.mercator-ocean.fr. Desde 2007, los resultados diarios 


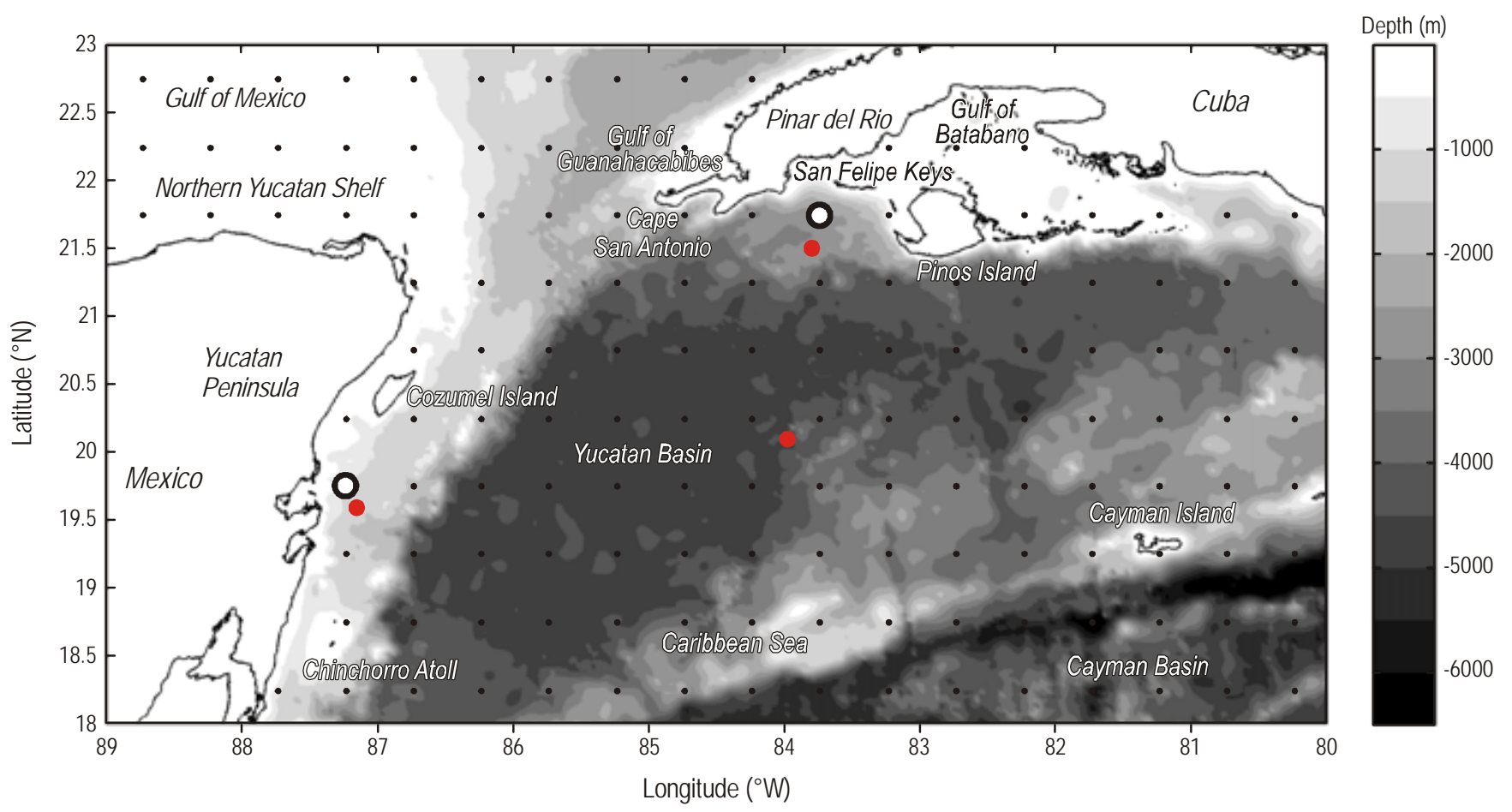

Figure 1. Bathymetric map (ETOPO-8.2) of the study area. Black dots represent the QuikSCAT wind product grid. Open circles show the locations where the strength of vertical transport and vertical eddy viscosity were computed. Red dots indicate the positions of the MERCATOR time series used to calculate vertical eddy diffusivity, gradient Richardson number, buoyancy frequency squared, and vertical shear flow. Bathymetry is shown in grey shading according to the scale on the right-hand side of the figure.

Figura 1. Mapa batimétrica (ETOPO-8.2) del área de estudio. Los puntos negros representan la red de datos de viento de QuikSCAT. Los círculos abiertos muestran los sitios donde se estimaron el transporte vertical advectivo y la viscosidad vertical de remolino. Los puntos rojos indican las posiciones de la serie de tiempo de MERCATOR que se usaron para calcular la difusividad vertical de remolino, el número de Richardson, la frecuencia de flotabilidad al cuadrado y la cizalladura vertical. La batimetría se muestra en tonos de gris según la escala a la derecha de la figura.

circulation patterns obtained with the MERCATOR model (supplement 1) agree with general circulation patterns generated by different ocean models for this region (e.g., Johns et al. 2002, Centurioni and Niiler 2003, Romanou et al. 2004, Jouanno et al. 2008).

\section{Quantification of mixing processes}

In order to quantify the influence of vertical advective transport and vertical diffusive transport on the mixing of the sea surface layer, the vertical advective transport $\left(W_{a d}\right)$ and the vertical eddy viscosity $\left(A_{z}\right)$ were calculated. To estimate $W_{a d}\left(W_{a d}=W_{E} D_{E}\right)$, the product of the Ekman pumping velocity $\left(W_{E}\right)$ and Ekman layer depth $\left(D_{E}\right)$ was determined. Positive values of $W_{a d}$ denoted upwelling and negative values indicated downwelling; negative values were excluded from the resulting figure in order to represent only the results of $W_{a d}$ related to the upwelling process.

$W_{E}$ was calculated from the wind stress curl according to Smith (1968): del modelo MERCATOR se distribuyen con una resolución espacial de $1 / 12^{\circ}(\sim 9 \times 9 \mathrm{~km})$ y 43 niveles verticales. La producción del modelo, consistente en datos de temperatura y salinidad del agua y corrientes oceánicas tridimensionales, se obtuvo de 2007 a 2009 en 36 niveles verticales para un dominio cubriendo el mar Caribe noroccidental entre $18^{\circ}-21.5^{\circ} \mathrm{N}$ y $80^{\circ}-88^{\circ} \mathrm{W}$. Los patrones de circulación obtenidos con el modelo MERCATOR (suplemento 1) coinciden con los patrones generales generados por diferentes modelos para esta región (e.g., Johns et al. 2002, Centurioni y Niiler 2003, Romanou et al. 2004, Jouanno et al. 2008).

\section{Cuantificación de los procesos de mezcla}

Para cuantificar la influencia del transporte vertical advectivo y la difusividad vertical en la mezcla de la capa superficial del mar, se calcularon el transporte vertical advectivo $\left(W_{a d}\right)$ y la viscosidad vertical de remolino $\left(A_{z}\right)$. Para estimar $W_{a d}\left(W_{a d}=W_{E} D_{E}\right)$, se determinó el producto de la velocidad de bombeo de Ekman $\left(W_{E}\right)$ y la profundidad de la capa de Ekman $\left(D_{E}\right)$. Los valores positivos de $W_{a d}$ indican 


$$
W_{E}=\frac{\nabla \times \vec{\tau}}{\rho f}
$$

where $\nabla \times \vec{\tau}$ is the wind stress curl and $\rho$ is water density; $f=2 \Omega \sin (\varphi)$ is the Coriolis parameter ( $\varphi$ is latitude). The wind stress curl was obtained through first-order finite centered differences. Cokriging extrapolation (Marcotte 1991) was applied to increase the resolution of wind stress curl data near the coast.

Wind stress $(\tau)$ was calculated by quadratic parameterization $\left(\tau_{\mathrm{x}}=\rho_{\text {air }} C_{d} U_{10 \mathrm{x}}\left|U_{10 s}\right|\right.$ and $\tau_{\mathrm{y}}=\rho_{\mathrm{air}} C_{d} U_{10 \mathrm{y}}\left|U_{10 s}\right|$ for the zonal (east-west) and for the meridional (north-south) components, respectively, where $U_{10 \mathrm{x}}$ and $U_{10 \mathrm{y}}$ are the wind components at $10 \mathrm{~m}$ height and $U_{10 \mathrm{~s}}$ is the wind magnitude at $10 \mathrm{~m}$ height). The drag coefficient $\left(C_{d}\right)$ was calculated as in Yelland and Taylor (1996) except during hurricanes Ivan and Wilma, for which wind stress was calculated using a constant drag coefficient of $2.8 \times 10^{-3}$ (Donelan et al. 2004).

$D_{E}$ (meters), at latitudes $(\varphi)$ beyond $+/-10^{\circ}$ of the equator, was computed as follows (Pond and Pickard 1983):

$$
D_{E}=\frac{4.3}{\sqrt{(\sin |\varphi|)}} U_{10 s}
$$

Then, $A_{z}$ was estimated according to Stewart (2008):

$$
A_{z}=\frac{D_{E}^{2} f}{2 \pi^{2}}
$$

Values for $W_{a d}, A_{z}$, and $D_{E}$ were obtained for each grid point of the QuikSCAT and H-Wind products. A time series of average values for each product was generated for the entire study domain. The time series at two specific points (fig. 1, open circles) were also chosen to illustrate changes near Cuba $\left(21.7^{\circ} \mathrm{N}, 83.7^{\circ} \mathrm{W}\right)$ and off the Yucatan Peninsula in the Caribbean Sea, south of the island of Cozumel $\left(19.7^{\circ} \mathrm{N}, 87.2^{\circ} \mathrm{W}\right)$. We sought to examine the relative contributions of $W_{a d}$ and $A_{z}$ diffusive transport in the Ekman layer depth as sources of nutrients from the subsurface to the surface. $W_{a d}$ represented the influence of the wind stress curl and pumping, and $A_{z}$ indicated the frictional effects caused by the surface wind.

Eddy viscocity represents the diffusivity of momentum associated with the wind stress. To also account for diffusivity of mass, the vertical eddy diffusivity $\left(K_{v}\right)$ was obtained from the temperature, salinity, and velocity profiles from the three-dimensional output of the MERCATOR model.

$K_{v}$ was computed using the parameterization proposed by Rodríguez-Santana et al. (1999), which incorporates two regimes: (a) low gradient Richardson number ( $R i)$ values, $K_{v}=1.1 \times 10^{-8} R i^{-9.2}, R i \leq 0.33$, and (b) high $R i$ values, surgencia y los valores negativos, hundimiento; en la figura resultante los valores negativos fueron excluidos y sólo se muestran los resultados de $W_{a d}$ favorables a la surgencia.

Se calculó $W_{E}$ a partir del rotacional del esfuerzo del viento según Smith (1968):

$$
W_{E}=\frac{\nabla \times \vec{\tau}}{\rho f}
$$

donde $\nabla \times \vec{\tau}$ es el rotacional del esfuerzo del viento y $\rho$ es la densidad del agua; $f=2 \Omega \sin (\varphi)$ es el parámetro de Coriolis ( $\varphi$ es la latitud). El rotacional del esfuerzo del viento se obtuvo a partir de diferencias finitas centradas de primer orden. Se realizó una extrapolación tipo "cokriging" (Marcotte 1991) para incrementar la resolución de los datos del rotacional del esfuerzo del viento cerca de la costa.

El esfuerzo del viento $(\tau)$ se calculó mediante la parametrización cuadrática $\left(\tau_{\mathrm{x}}=\rho_{\text {aire }} C_{d} U_{10 \mathrm{x}}\left|U_{10 s}\right|\right.$ y $\tau_{\mathrm{y}}=$ $\rho_{\text {aire }} C_{d} U_{10 \mathrm{y}}\left|U_{10 \mathrm{~s}}\right|$ para los componentes zonal (este-oeste) y meridional (norte-sur), respectivamente, donde $U_{10 \mathrm{x}}$ y $U_{10 \mathrm{y}}$ son las componentes del viento a $10 \mathrm{~m}$ de altura y $U_{10 \mathrm{~s}}$ es la magnitud del viento a $10 \mathrm{~m}$ de altura). El coeficiente de arrastre $\left(C_{d}\right)$ se calculó siguiendo a Yelland y Taylor (1996), excepto durante los huracanes Iván y Wilma, cuando el esfuerzo del viento se calculó con un coeficiente de arrastre constante de $2.8 \times 10^{-3}$ (Donelan et al. 2004).

Se calculó $D_{E}$ (metros), a latitudes $(\varphi)+/-10^{\circ}$ del ecuador, como sigue (Pond y Pickard 1983):

$$
D_{E}=\frac{4.3}{\sqrt{(\sin |\varphi|)}} U_{10 s}
$$

Luego, se estimó $A_{z}$ según Stewart (2008):

$$
A_{z}=\frac{D_{E}^{2} f}{2 \pi^{2}}
$$

Los valores para $W_{a d}, A_{z}$ y $D_{E}$ fueron obtenidos para cada punto de las redes de los productos de H-Wind y QuikSCAT. Se generó una serie de tiempo de valores promedios para cada producto para toda la zona de estudio. También se eligieron las series de tiempo de dos puntos específicos (fig. 1, círculos abiertos) para ilustrar los cambios cerca de Cuba $\left(21.7^{\circ} \mathrm{N}, 83.7^{\circ} \mathrm{W}\right)$ y de la península de Yucatán en el mar Caribe, al sur de la isla de Cozumel $\left(19.7^{\circ} \mathrm{N}, 87.2^{\circ} \mathrm{W}\right)$. Se pretendió analizar las contribuciones relativas de $W_{a d}$ y el transporte difusivo de $A_{z}$ en la profundidad de la capa de Ekman como fuentes de nutrientes de la subsuperficie a la superficie; $W_{a d}$ representó la influencia del rotacional del esfuerzo del viento y el bombeo, y $A_{z}$ indicó los efectos de fricción causados por el viento en la superficie. 
$K_{v}=2.6 \times 10^{-3}(1+10 R i)^{-3 / 2}, R i>0.33 . R i$ was defined as follows:

$$
R i=\frac{N^{2}}{S^{2}}
$$

where $N$ is the buoyancy frequency, representing the stability of the water column, and $S^{2}$ is the vertical shear flow. $S^{2}$ was calculated using vertical central differences:

$$
S^{2}=\left(\frac{\delta u}{\delta z}\right)^{2}+\left(\frac{\delta v}{\delta z}\right)^{2}
$$

where $u$ and $v$ are the zonal and meridional current components obtained from the MERCATOR model. Values of $K_{v}$, $R i, N^{2}$, and $S^{2}$ were computed at three different locations (fig. 1, red points): Yucatan Basin $\left(20.1^{\circ} \mathrm{N}, 84^{\circ} \mathrm{W}\right)$, southwest of Cuba $\left(21.5^{\circ} \mathrm{N}, 83.8^{\circ} \mathrm{W}\right)$, and southeast of the Yucatan Peninsula $\left(19.6^{\circ} \mathrm{N}, 87.2^{\circ} \mathrm{W}\right)$.

\section{Satellite chlorophyll-a data}

Satellite-derived images of chl- $a$ concentrations were obtained from the Moderate Resolution Imaging Spectroradiometer (MODIS) sensor onboard the Aqua satellite. MODISAqua provides a daily product of surface ocean chl- $a$ concentration with a spatial resolution of approximately $1 \mathrm{~km}^{2}$ per pixel at nadir over cloud-free ocean areas. Chl- $a$ concentrations for the Yucatan Basin $\left(18^{\circ}-22^{\circ} \mathrm{N}\right.$, $80^{\circ}-86.5^{\circ} \mathrm{W}$ ) were extracted using SeaDAS 6.1 software.

To confirm that the chl- $a$ patterns observed were indeed related to phytoplankton blooms, the fluorescence line height (FLH) products from MODIS-Aqua were also analyzed. These FLH products were processed similarly to chl- $a$ products following Letelier and Abbott (1996). For purposes of this study, shallow areas or those near the coast were not considered for the chl-a or FLH analysis (e.g., Gulf of Batabanó, fig. 1).

To investigate the ocean response to synoptic-scale meteorological events, daily chl- $a$ concentration and FLH images were analyzed before, during, and after hurricanes Ivan (2-24 September 2004) and Wilma (15-25 October 2005). Other synoptic-scale meteorological events were also analyzed in 2004 and 2005, such as cold fronts, low-pressure systems, and tropical waves. For this paper we selected one or two relatively cloud-free images that best represented the chl- $a$ distributions associated with each wind event.

\section{Dynamic topography obtained from altimetry}

We used the Salto/Duacs altimeter products developed by the CNES (Centre National d'Études Spatiales, France; http://www.aviso.oceanobs.com/). This database has a temporal resolution of 7 days and a spatial resolution of $1 / 3^{\circ}$. The
La viscosidad de remolino representa la difusividad de momento asociada con el esfuerzo del viento. Para también considerar la difusividad de masa, se obtuvo la difusividad vertical de remolino $\left(K_{v}\right)$ de los perfiles de temperatura, salinidad y velocidad de los resultados tridimensionales del modelo MERCATOR.

Se calculó $K_{v}$ mediante la parametrización propuesta por Rodríguez-Santana et al. (1999), la cual incorpora dos regímenes: (a) valores bajos del número de Richardson $(R i)$, $K_{v}=1.1 \times 10^{-8} R i^{-9.2}, R i \leq 0.33$, y (b) valores altos de $R i$, $K_{v}=2.6 \times 10^{-3}(1+10 R i)^{-3 / 2}, R i>0.33$. Se definió $R i$ como sigue:

$$
R i=\frac{N^{2}}{S^{2}}
$$

donde $N$ es la frecuencia de flotabilidad, representando la estabilidad de la columna de agua, y $S^{2}$ es la cizalladura vertical. Esta última se calculó usando diferencias centrales en la vertical:

$$
S^{2}=\left(\frac{\delta u}{\delta z}\right)^{2}+\left(\frac{\delta v}{\delta z}\right)^{2}
$$

donde $u$ y $v$ son los componentes zonal y meridional de la corriente obtenidos del modelo MERCATOR. Los valores de $K_{v}, R i, N^{2}$ y $S^{2}$ fueron calculados en tres sitios distintos (fig. 1, puntos rojos): la cuenca de Yucatán $\left(20.1^{\circ} \mathrm{N}, 84^{\circ} \mathrm{W}\right)$, al suroeste de Cuba $\left(21.5^{\circ} \mathrm{N}, 83.8^{\circ} \mathrm{W}\right)$ y al sureste de la península de Yucatán $\left(19.6^{\circ} \mathrm{N}, 87.2^{\circ} \mathrm{W}\right)$.

\section{Datos satelitales de clorofila $a$}

Las imágenes de clorofila superficial fueron provistas por el sensor Moderate Resolution Imaging Spectroradiometer (MODIS) a bordo del satélite Aqua. Este sensor proporciona datos diarios de la concentración de clorofila $a$ en la superficie del mar con una resolución espacial de aproximadamente $1 \mathrm{~km}^{2}$ por pixel al nadir sobre áreas del océano libres de nubes. Las concentraciones de clorofila $a$ para la cuenca de Yucatán $\left(18^{\circ}-22^{\circ} \mathrm{N}, 80^{\circ}-86.5^{\circ} \mathrm{W}\right)$ fueron obtenidas con el paquete SeaDAS 6.1.

Para confirmar que los patrones de clorofila $a$ estuvieran efectivamente relacionados con afloramientos fitoplanctónicos, también se analizaron los datos de la altura de la línea de fluorescencia (FLH, por sus siglas en inglés) de MODISAqua. Estos datos fueron procesados de forma similar a los de clorofila a siguiendo a Letelier y Abbott (1996). Para el propósito de este estudio, no se consideraron zonas someras o cerca de la costa para el análisis de FLH o clorofila $a$ (e.g., golfo de Batabanó, fig. 1).

Para analizar la respuesta del océano a fenómenos meteorológicos de escala sinóptica, se analizaron imágenes diarias 
zonal and meridional components of the absolute geostrophic currents were obtained from the MADT (Map of Absolute Dynamic Topography) product distributed by CNES.

\section{RESULTS}

\section{Quantification of mixing processes}

The three time series of vertical eddy viscosity $\left(A_{z}\right)$ showed a similar annual cycle that peaked in November and December (10-15 $\times 10^{-3} \mathrm{~m}^{2} \mathrm{~s}^{-1}$; fig. 2a-c). Starting in January, $A_{z}$ diminished reaching its lowest value $\left(\sim 3 \times 10^{-3} \mathrm{~m}^{2} \mathrm{~s}^{-1}\right)$ around the beginning of September. A small secondary relative maximum was observed in June $\left(10-12 \times 10^{-3} \mathrm{~m}^{2} \mathrm{~s}^{-1}\right)$. In general, vertical transport velocities $\left(W_{a d}\right)$ were two orders of magnitude lower than the values of $A_{z}$ and they were always favorable to upwelling (positive values). No annual cycle for $W_{a d}$ could be observed in the averages for the entire region (fig. 2d-f). Several isolated maxima, at least one order of magnitude higher than the regional average, could be observed in the climatology off southern Cuba in May/June and October/November, corresponding to the hurricane season in the region. The Ekman layer depth $\left(D_{E}\right)$ ranged from 40 to $60 \mathrm{~m}$ all year round, with the minimum (maximum) during the summer (winter). Minimum $D_{E}$ was also registered in September (fig. $2 \mathrm{~g}-\mathrm{i}$ ).

The maximum values of vertical eddy diffusivity $\left(K_{v}\right)$ were found near the mixed layer depth in the region, as characterized by the three different locations, with magnitudes of $K_{v}=10^{-5}-10^{-3} \mathrm{~m}^{2} \mathrm{~s}^{-1}$ (fig. 3a-c). The time series of $K_{v}$ for eastern Yucatan was different from the series for southern Cuba and the central Yucatan Basin, showing high variability below the mixed layer depth, from $\sim 50$ to $250 \mathrm{~m}$ depth. Its seasonal median was one order of magnitude higher, with the greatest $K_{v}\left(0.27 \mathrm{~m}^{2} \mathrm{~s}^{-1}\right)$ at midyear (table 1$)$. As expected, the gradient Richardson number ( $R i)$ was inversely related to $K_{v}$ (fig. $3 \mathrm{~d}-\mathrm{f}$ ). Low values of $R i$ were observed during spring and summer, indicating favorable conditions for vertical mixing, but strong stratification led instead to high buoyancy frequency $\left(N^{2}, 2-4 \times 10^{-4} \mathrm{~s}^{-2}\right)$ and decreased mixing (fig. $3 \mathrm{~g}-\mathrm{i}$ ). Vertical shear $\left(S^{2}\right)$ was high in the first $50 \mathrm{~m}$ $\left(10^{-5}-10^{-4} \mathrm{~s}^{-2}\right)$ of the water column, with a second maximum zone between 70 and $200 \mathrm{~m}$ (fig. 3j-1). Maximum values of $S^{2}$ reached the surface in spring and summer, and deepened in autumn and winter.

\section{Analysis of vertical advective transport $\left(W_{a d}\right)$, vertical eddy viscosity $\left(A_{z}\right)$, and Ekman layer depth $\left(D_{E}\right)$ during synoptic-scale meteorological events}

\section{Cold front}

During the influence of a cold front (7 November 2004), winds were northerly with mean velocities of $8.7 \mathrm{~m} \mathrm{~s}^{-1}$ and wind stress increased toward the south with maximum values de la concentración de clorofila $a$ y FLH antes, durante y después de los huracanes Iván (2-24 de septiembre de 2004) y Wilma (15-25 de octubre de 2005). También se analizaron otros eventos meteorológicos de escala sinóptica en 2004 y 2005, tales como frentes fríos, sistemas de baja presión y ondas tropicales. Para este estudio, se seleccionaron una o dos imágenes relativamente libres de nubes que mejor representaban la distribución de clorofila $a$ asociada con cada evento.

\section{Topografía dinámica obtenida por altimetría}

Se usaron los datos del altímetro Salto/Duacs proporcionados por CNES (Centre National d'Études Spatiales, Francia; http://www.aviso.oceanobs.com/). Esta base de datos tiene una resolución temporal de 7 días y una resolución espacial de $1 / 3^{\circ}$. Los componentes zonal y meridional de las corrientes geostróficas absolutas fueron obtenidas del producto MADT (Map of Absolute Dynamic Topography) distribuido por CNES.

\section{RESUlTADOS}

\section{Quantificación de los procesos de mezcla}

Las tres series de tiempo de la viscosidad vertical de remolino $\left(A_{z}\right)$ mostraron un ciclo anual similar con valores máximos $\left(10-15 \times 10^{-3} \mathrm{~m}^{2} \mathrm{~s}^{-1}\right)$ en noviembre y diciembre (fig. 2a-c). A partir de enero, la $A_{z}$ decreció hasta alcanzar su valor mínimo $\left(\sim 3 \times 10^{-3} \mathrm{~m}^{2} \mathrm{~s}^{-1}\right)$ a principios de septiembre, observándose un segundo máximo relativo secundario en junio $\left(10-12 \times 10^{-3} \mathrm{~m}^{2} \mathrm{~s}^{-1}\right)$. En general, las velocidades de transporte vertical $\left(W_{a d}\right)$ fueron dos órdenes de magnitud menores que los valores de $A_{z}$ y siempre fueron favorables para la surgencia (valores positivos). No fue posible observar un ciclo anual para $W_{a d}$ en los promedios para toda la región (fig. 2d-f). Se observaron varios máximos aislados, por lo menos un orden de magnitud mayor que el promedio regional, en la climatología al sur de Cuba en mayo/junio y octubre/noviembre, coincidiendo con la temporada de huracanes en la región. La profundidad de la capa de Ekman $\left(D_{E}\right)$ osciló entre 40 y $60 \mathrm{~m}$ todo el año, con el mínimo (máximo) durante el verano (invierno). La $D_{E}$ mínima también se registró en septiembre (fig. $2 \mathrm{~g}-\mathrm{i}$ ).

Los valores máximos de la difusividad vertical de remolino $\left(K_{v}\right)$ fueron registrados cerca de la profundidad de la capa de mezcla en la región conformada por los tres sitios diferentes, con magnitudes de $K_{v}=10^{-5}-10^{-3} \mathrm{~m}^{2} \mathrm{~s}^{-1}$ (fig. 3a-c). La serie de tiempo de $K_{v}$ para el este de Yucatán difirió de la serie para el sur de Cuba y la parte central de la cuenca de Yucatán, mostrando gran variabilidad por debajo de la profundidad de la capa de mezcla, de $\sim 50$ a $250 \mathrm{~m}$ de profundidad. Su mediana estacional fue un orden de magnitud mayor, registrándose el valor más elevado de 

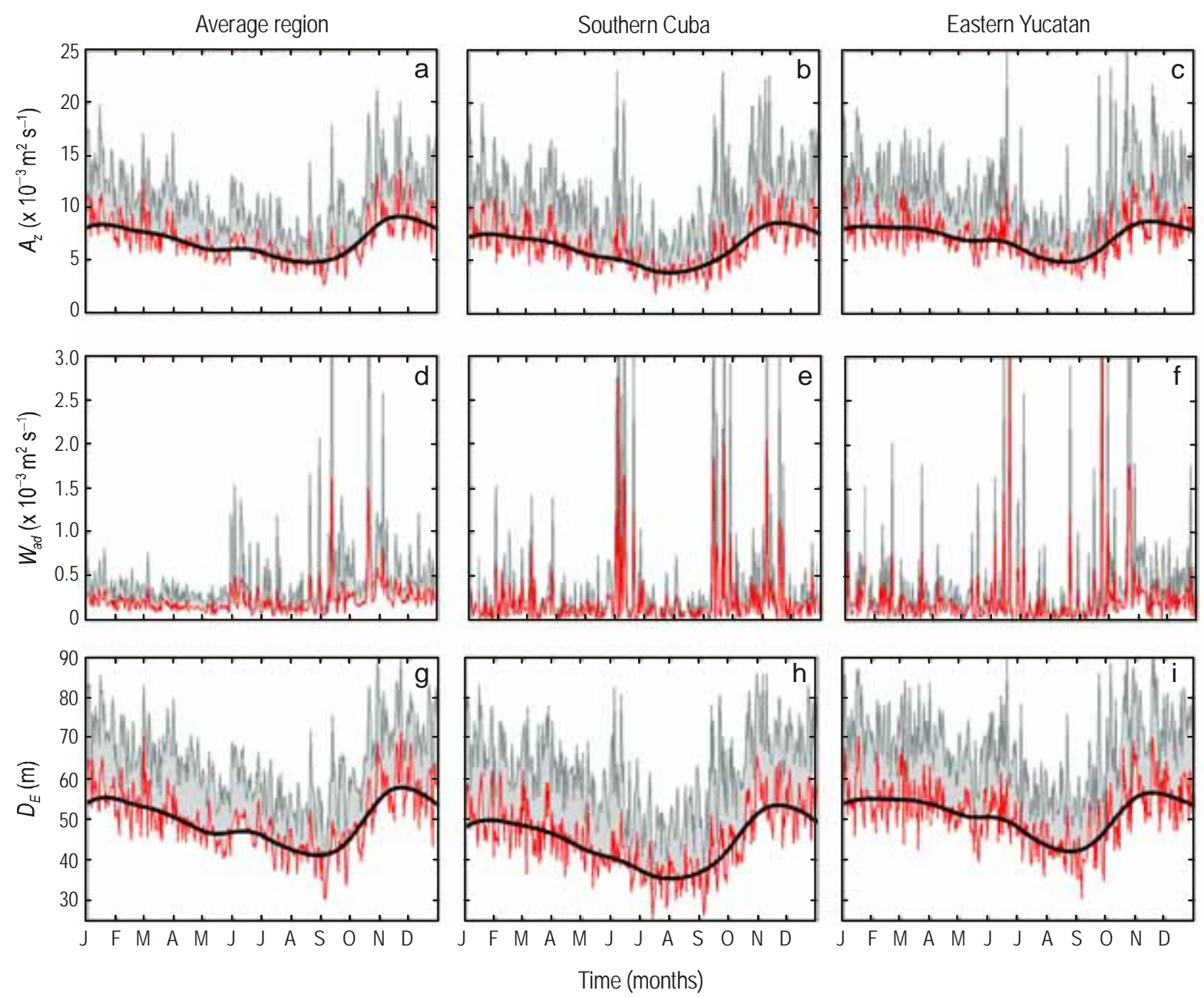

Figure 2. An approximation of the climatology (yearly means for the period 21 November 1999 to 21 November 2009). Red lines show the seasonal variation of $(\mathbf{a}-\mathbf{c})$ vertical eddy viscosity coefficient $\left(A_{z}\right),(\mathbf{d}-\mathbf{f})$ vertical transport $\left(W_{a d}\right)$, and $(\mathbf{g}-\mathbf{i})$ surface Ekman layer depth $\left(D_{E}\right)$. Black lines correspond to a 30-day Lanczos cosine low-pass filtered time series. Grey lines represent the positive standard deviations. The left column depicts the regional average including all QuikSCAT grid points. The central and right columns correspond to southern Cuba and eastern Yucatan points, respectively, highlighted by open circles in figure 1.

Figura 2. Aproximación de la climatología (promedios anuales para el periodo del 21 de noviembre de 1999 al 21 de noviembre de 2009 ). Las líneas rojas muestran la variación estacional de $(\mathbf{a}-\mathbf{c})$ el coeficiente de la viscosidad vertical de remolino $\left(A_{z}\right)$, $(\mathbf{d}-\mathbf{f})$ el transporte vertical $\left(W_{a d}\right)$ y $(\mathbf{g}-\mathbf{i})$ la profundidad de la capa de Ekman $\left(D_{E}\right)$. Las líneas negras corresponden a una serie de tiempo de 30 días filtrada con un filtro de paso bajo Lanczos (coseno). Las líneas grises representan las desviaciones estándar positivas. La columna izquierda muestra el promedio regional que incluye todos los puntos de la red de QuikSCAT. Las columnas central y derecha corresponden a los puntos al sur de Cuba y este de Yucatán, respectivamente, indicados con círculos abiertos en la figura 1.

of $0.28 \mathrm{~Pa}$ in the southern Yucatan Basin (fig. 4a), which resulted in a relatively high $A_{z}\left(23.1 \times 10^{-3} \mathrm{~m}^{2} \mathrm{~s}^{-1}\right.$, fig. $\left.4 \mathrm{~b}\right)$. Zonal and meridional gradients of the wind stress added up to a positive wind stress curl that resulted in positive $W_{a d}$ values $\left(1.3 \times 10^{-3} \mathrm{~m}^{2} \mathrm{~s}^{-1}\right)$ for most of the Yucatan Basin (fig. 4a), corresponding to extreme peaks as observed in the yearly mean time series (fig. 2).

\section{Easterly tropical wave}

From 3 to 5 July 2005, during the passage of an easterly tropical wave through the Yucatan Basin, strong winds
$K_{v}\left(0.27 \mathrm{~m}^{2} \mathrm{~s}^{-1}\right)$ a mediados de año (tabla 1$)$. Como se esperaba, el número de Richardson (Ri) mostró una relación inversa a $K_{v}$ (fig. $3 \mathrm{~d}-\mathrm{f}$ ). En primavera y verano se observaron valores bajos de $R i$, lo cual indica condiciones favorables para la mezcla vertical; sin embargo, una fuerte estratificación resultó en una frecuencia de flotabilidad alta $\left(N^{2}\right.$, $2-4 \times 10^{-4} \mathrm{~s}^{-2}$ ) y mezcla reducida (fig. $3 \mathrm{~g}-\mathrm{i}$ ). La cizalladura vertical $\left(S^{2}\right)$ fue alta en los primeros $50 \mathrm{~m}\left(10^{-5}-10^{-4} \mathrm{~s}^{-2}\right)$ de la columna de agua, con una segunda zona máxima entre $70 \mathrm{y}$ $200 \mathrm{~m}$ (fig. 3j-1). Los valores máximos de $S^{2}$ se registraron en la superficie en primavera y verano, y a mayores profundidades en otoño e invierno. 

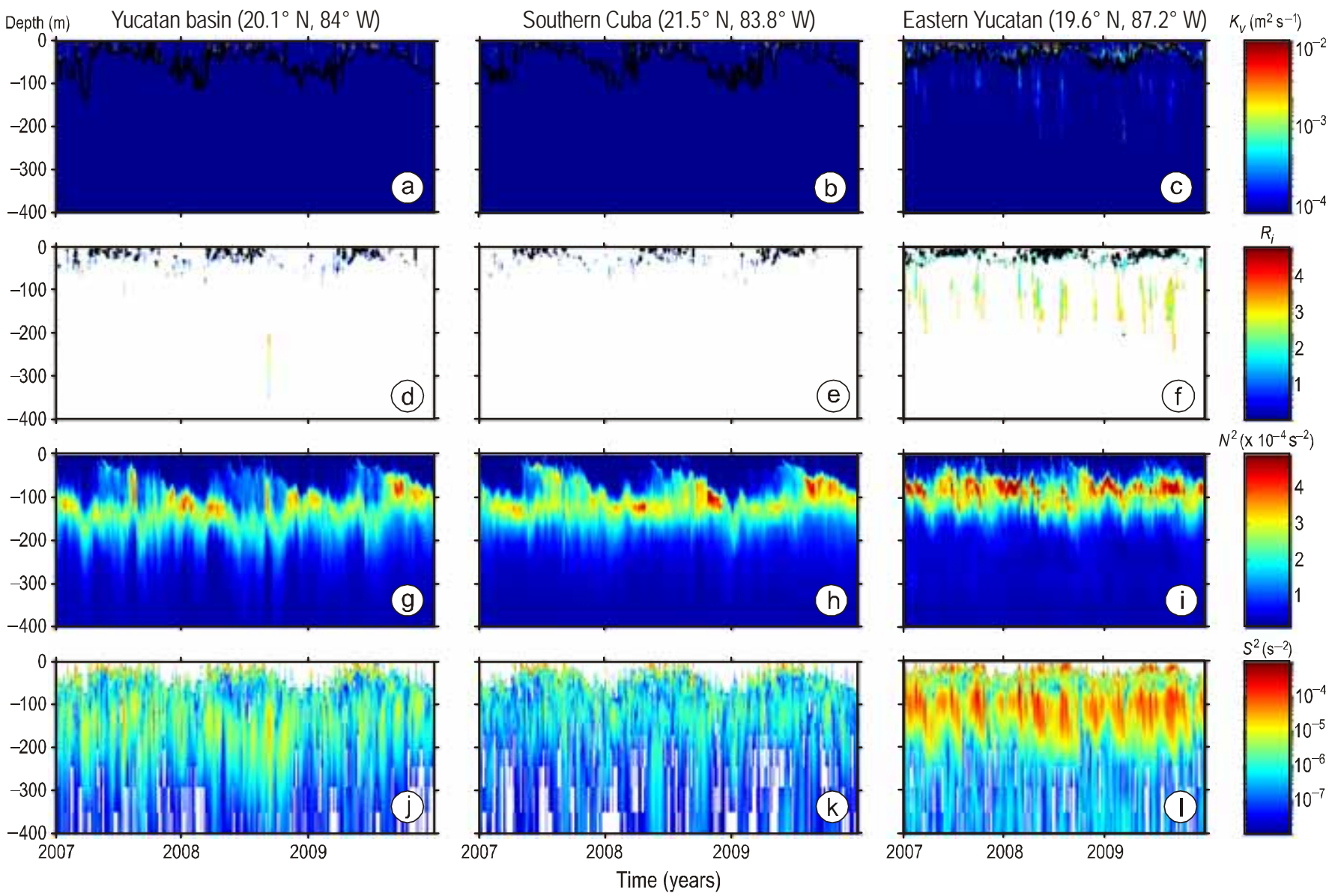

Figure 3. Daily time series of the (a-c) vertical density eddy diffusivity $\left(K_{v}\right)$, $(\mathbf{d}-\mathbf{f})$ gradient Richardson number (Ri), (g-i) buoyancy frequency squared $\left(N^{2}\right)$, and $(\mathbf{j}-\mathbf{l})$ vertical shear $\left(S^{2}\right)$ derived from MERCATOR model data during the period 2007 to 2009 . In (a-c), the black solid line represents the mixed layer depth calculated according to Lorbacher et al. (2006). In (d-f), values of $R i>5$ were excluded from the figure.

Figura 3. Series de tiempo de (a-c) la difusividad vertical de remolino $\left(K_{v}\right)$, $(\mathbf{d}-\mathbf{f})$ el número de Richardson $(R i)$, (g-i) la frecuencia de flotabilidad al cuadrado $\left(N^{2}\right)$ y $(\mathbf{j}-\mathbf{l})$ la cizalladura vertical $\left(S^{2}\right)$ derivadas de datos diarios del modelo MERCATOR durante el periodo de 2007 a 2009. En (a-c), la línea negra sólida representa la profundidad de la capa de mezcla estimada de acuerdo con Lorbacher et al. (2006). En (d-f) se excluyeron los valores de $R i>5$.

(mean of $9.4 \mathrm{~m} \mathrm{~s}^{-1}$, table 2) were observed from a southeasterly direction. Wind stress peaked at $0.49 \mathrm{~Pa}$ (fig. $4 \mathrm{c}$ ), or $A_{\mathrm{z}}$ of approximately $33 \times 10^{-3} \mathrm{~m}^{2} \mathrm{~s}^{-1}$ (fig. 4d). Vertical advective velocities were upward in the central and eastern Yucatan Basin (fig. 4c), with maximum vertical transport $\left(4.8 \times 10^{-3} \mathrm{~m}^{2} \mathrm{~s}^{-1}\right)$ higher than the yearly mean, but low compared to $A_{z}$. The maximum values were located in the western Yucatan Basin, between the island of Cozumel and Chinchorro Atoll.

\section{Low-pressure system}

A low-pressure system passed over Pinar del Río (western Cuba) on 5 October 2005 (fig. 4e). Mean wind speed was moderate over most of the region $\left(6.3 \mathrm{~m} \mathrm{~s}^{-1}\right.$, table 2), with highest values $\left(18.27 \mathrm{~m} \mathrm{~s}^{-1}\right)$ off the eastern
Análisis del transporte advectivo vertical $\left(W_{a d}\right)$, la viscosidad vertical de remolino $\left(A_{z}\right)$ y la profundidad de la capa de Ekman $\left(D_{E}\right)$ durante fenómenos meteorológicos de escala sinóptica

\section{Frente frío}

Durante la influencia de un frente frío (7 de noviembre de 2004), los vientos soplaron del norte con una velocidad media de $8.7 \mathrm{~m} \mathrm{~s}^{-1}$ y el esfuerzo del viento se incrementó hacia el sur con valores máximos de $0.28 \mathrm{~Pa}$ en la parte sur de la cuenca de Yucatán (fig. 4a), que resultó en una $A_{z}$ relativamente alta $\left(23.1 \times 10^{-3} \mathrm{~m}^{2} \mathrm{~s}^{-1}\right.$, fig. $\left.4 \mathrm{~b}\right)$. Los gradientes zonal y meridional del esfuerzo del viento indicaron un rotacional positivo de $W_{a d}\left(1.3 \times 10^{-3} \mathrm{~m}^{2} \mathrm{~s}^{-1}\right)$ para la mayor parte de la cuenca de Yucatán (fig. 4a), correspondiendo a picos 
Table 1. Median of the vertical eddy diffusivity $\left(K_{v}\right)$, the gradient Richardson number (Ri), and the mixed layer depth (MLD) time series (2007 to 2009) (MERCATOR output) for the locations off southern Cuba and eastern Yucatan.

Tabla 1. Mediana de la serie de tiempo (2007 a 2009) de la difusividad vertical de remolino $\left(K_{v}\right)$, el número de Richardson (Ri) y la profundidad de la capa de mezcla (MLD) (datos de MERCATOR) para los sitios al sur de Cuba y este de Yucatán.

\begin{tabular}{|c|c|c|c|c|c|}
\hline & Median & $\begin{array}{c}\text { Winter } \\
\text { (Jan., Feb., Mar.) }\end{array}$ & $\begin{array}{c}\text { Spring } \\
\text { (Apr., May, June) }\end{array}$ & $\begin{array}{c}\text { Summer } \\
\text { (July, Aug., Sep.) }\end{array}$ & $\begin{array}{c}\text { Autumn } \\
\text { (Oct., Nov., Dec.) }\end{array}$ \\
\hline \multicolumn{6}{|l|}{ Southern Cuba } \\
\hline$K_{v} \mathrm{~m}(\mathrm{~m})$ & 27.3 & 43.8 & 14.6 & 17.1 & 51.5 \\
\hline$R i \min .\left(\mathrm{m}^{2} \mathrm{~s}^{-1}\right)$ & 0.76 & 1.25 & 0.22 & 0.50 & 2.03 \\
\hline $\operatorname{MLD}(\mathrm{m})$ & 42.5 & 78.4 & 22.4 & 25.1 & 59.2 \\
\hline \multicolumn{6}{|l|}{ Eastern Yucatan } \\
\hline$K_{v} \max .\left(\mathrm{m}^{2} \mathrm{~s}^{-1}\right)$ & $1.6 \times 10^{-3}$ & $1.8 \times 10^{-4}$ & $8.8 \times 10^{-1}$ & $2.7 \times 10^{-1}$ & $1.2 \times 10^{-4}$ \\
\hline$K_{v} \mathrm{~m}(\mathrm{~m})$ & 20.0 & 27.3 & 10.4 & 8.7 & 31.9 \\
\hline
\end{tabular}

$K_{v} \mathrm{~m}$ and Rim represent the depth of the maximum value of $K_{v}$ max. and $R i \min$.

Yucatan Peninsula. Wind stress there peaked at a maximum of $0.75 \mathrm{~Pa}$ (fig. $4 \mathrm{e}$ ), resulting in the highest $A_{z}$ value $\left(\sim 45 \times 10^{-3} \mathrm{~m}^{2} \mathrm{~s}^{-1}\right)$ in the category of moderate meteorological events (fig. 4f). Vertical advective velocities were strongly upward south of $20^{\circ} \mathrm{N}$ (fig. 4e), with maximum velocities $\left(7.8 \times 10^{-3} \mathrm{~m}^{2} \mathrm{~s}^{-1}\right)$ along the coast.

\section{Hurricanes}

Along the track of Hurricane Ivan (category 5, maximum wind speeds of $68.5 \mathrm{~m} \mathrm{~s}^{-1}$, maximum wind stress of $15.7 \mathrm{~Pa}$; table 2), the $W_{a d}$ values (fig. 5a) were one order of magnitude greater (maximum of $8.4 \mathrm{~m}^{2} \mathrm{~s}^{-1}$ ) than those of $A_{z}$, thereby reversing the relative importance of advective transport compared to that during weak or moderate meteorological events. During the hurricane, $A_{z}$ was still high, with maximum values of $0.64 \mathrm{~m}^{2} \mathrm{~s}^{-1}$ (fig. 5b). This is about three times higher than the regional yearly mean (fig. 2), reflecting the mixing power of hurricanes.

During Hurricane Wilma (category 4), similar wind mixing and Ekman pumping were observed. $W_{a d}\left(5.4 \mathrm{~m}^{2} \mathrm{~s}^{-1}\right)$ was one order of magnitude higher than $A_{\mathrm{z}}\left(0.45 \mathrm{~m}^{2} \mathrm{~s}^{-1}\right)$ when Wilma moved through the Yucatan Basin, with maximum speeds of $57.6 \mathrm{~m} \mathrm{~s}^{-1}$ and maximum wind stress of $11.1 \mathrm{~Pa}$ (fig. 5c, d; table 2). As with Hurricane Ivan, the maximum values of $W_{a d}$ and $A_{z}$ were located in an area $\sim 100 \times 100 \mathrm{~km}$ and $\sim 300 \times 300 \mathrm{~km}$, respectively, around the eye of the hurricane (inlays fig. $5 \mathrm{a}, \mathrm{c}$ ).

The $D_{E}$ reached maximum values of $103 \mathrm{~m}$ during the passage of the cold front, $115 \mathrm{~m}$ during the easterly tropical extremos como se observó en la serie de tiempo promedio anual (fig. 2).

\section{Onda tropical del este}

Del 3 al 5 de julio de 2005, durante el paso de una onda tropical del este por la cuenca de Yucatán, soplaron vientos fuertes del sureste con una velocidad media de $9.4 \mathrm{~m} \mathrm{~s}^{-1}$ (tabla 2). El esfuerzo del viento fue máximo a $0.49 \mathrm{~Pa}$ (fig. 4c), con una $A_{\mathrm{z}}$ de aproximadamente $33 \times 10^{-3} \mathrm{~m}^{2} \mathrm{~s}^{-1}$ (fig. 4d). La velocidad vertical advectiva fue hacia arriba en las partes central y este de la cuenca de Yucatán (fig. 4c), con un transporte vertical máximo $\left(4.8 \times 10^{-3} \mathrm{~m}^{2} \mathrm{~s}^{-1}\right)$ mayor que la media anual, pero bajo comparado con $A_{z}$. Los valores máximos se registraron en la parte oeste de la cuenca, entre la isla de Cozumel y el banco Chinchorro.

\section{Sistema de baja presión}

Un sistema de baja presión pasó sobre Pinar del Río (oeste de Cuba) el 5 de octubre de 2005 (fig. 4e). La velocidad media del viento fue moderada en la mayor parte de la región (6.3 $\mathrm{m} \mathrm{s}^{-1}$, tabla 2), registrándose los mayores valores $\left(18.27 \mathrm{~m} \mathrm{~s}^{-1}\right)$ al este de la península de Yucatán. Ahí, el esfuerzo del viento presentó un máximo de $0.75 \mathrm{~Pa}$ (fig. 4e), lo cual resultó en el valor más alto de $A_{z}(\sim 5 \times$ $\left.10^{-3} \mathrm{~m}^{2} \mathrm{~s}^{-1}\right)$ en la categoría de eventos meteorológicos moderados (fig. 4f). Las velocidades advectivas verticales fueron fuertemente hacia arriba al sur de $20^{\circ} \mathrm{N}$ (fig. 4e), con velocidades máximas $\left(7.8 \times 10^{-3} \mathrm{~m}^{2} \mathrm{~s}^{-1}\right)$ en la costa. 

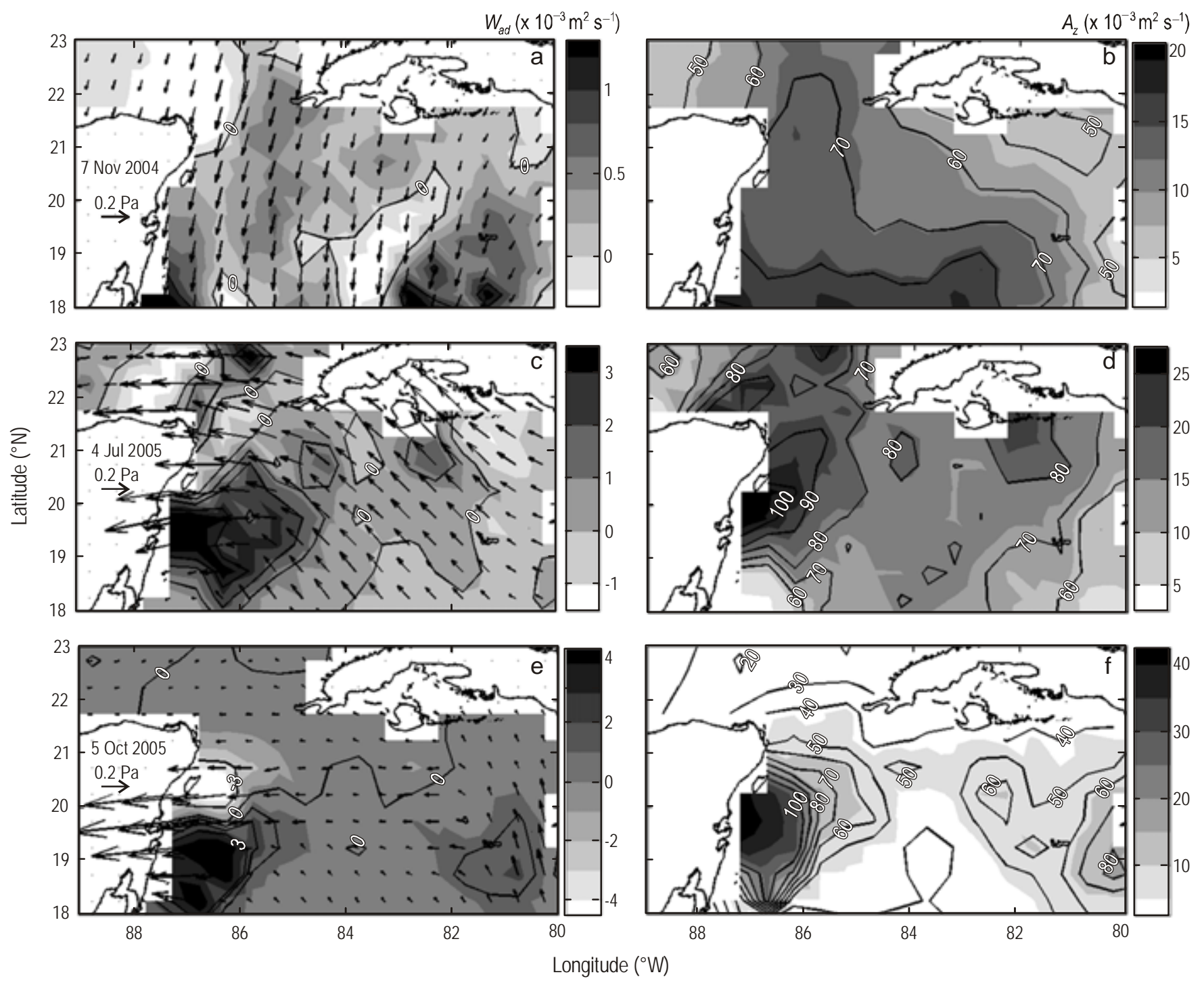

Figure 4. Vertical transport ( $W_{a d}$, grey-shaded with zero black contour line) and vertical eddy viscosity coefficient $\left(A_{z}\right.$, grey-shaded), during moderate meteorological events: (a, b) cold front (7 November 2004), (c, d) tropical wave (4 July 2005), and (e, f) low-pressure system (5 October 2005). Black arrows in (a), (c), and (e) indicate wind stress vectors (Pa, a reference vector, is plotted on the Yucatan Peninsula). Solid black contour lines in (b), (d), and (f) represent the surface Ekman layer depth (m).

Figura 4. Transporte vertical ( $W_{a d}$, tonos de gris con línea negra de contorno cero) y coeficiente de la viscosidad vertical de remolino ( $A_{z}$, tonos de gris), durante eventos meteorológicos moderados: (a, b) frente frío (7 de noviembre de 2004), (c, d) onda tropical (4 de julio de 2005) y (e, f) sistema de baja presión (5 de octubre de 2005). Las flechas negras en (a), (c) y (e) indican vectores del esfuerzo del viento ( $\mathrm{Pa}$, un vector de referencia, se muestra para la península de Yucatán). Las líneas negras de contorno en (b), (d) y (f) representan la profundidad de la capa de Ekman (m).

wave, and $135 \mathrm{~m}$ during the low-pressure system. The deepest $D_{E}$ were observed around the eyes of hurricanes Ivan and Wilma, at 505 and $440 \mathrm{~m}$, respectively (figure not shown). Both values were registered to the right side of the eye of the two hurricanes. These values were overestimated because water column stability was not included in the calculations.

\section{Chlorophyll-a response}

Satellite-derived chl- $a$ concentration images collected during and after the passage of these synoptic meteorological

\section{Huracanes}

A lo largo de la trayectoria del huracán Iván (categoría 5, velocidad máxima del viento de $68.5 \mathrm{~m} \mathrm{~s}^{-1}$, esfuerzo máximo del viento de $15.7 \mathrm{~Pa}$; tabla 2), los valores de $W_{a d}$ (fig. 5a) fueron un orden de magnitud mayor (máximo de $8.4 \mathrm{~m}^{2} \mathrm{~s}^{-1}$ ) que los de $A_{z}$, revirtiendo así la importancia relativa del transporte advectivo comparado con el observado durante los eventos meteorológicos débiles o moderados. Durante el huracán, $A_{z}$ aún fue alta, con valores máximos de $0.64 \mathrm{~m}^{2} \mathrm{~s}^{-1}$ (fig. 5b); esto es alrededor de tres veces mayor que la media 
Table 2. Statistical characteristics of vertical eddy viscosity $\left(A_{z}\right)$, vertical advective transport $\left(W_{a d}\right)$, and Ekman layer depth $\left(D_{E}\right)$ during the passage of synoptic-scale meteorological events over the Yucatan Basin.

Tabla 2. Características estadísticas de la viscosidad vertical de remolino $\left(A_{z}\right)$, el transporte vertical advectivo $\left(W_{a d}\right)$ y la profundidad de la capa de Ekman $\left(D_{E}\right)$ durante el paso de eventos meteorológicos de escala sinóptica por la cuenca de Yucatán.

\begin{tabular}{|c|c|c|c|c|c|c|c|c|c|}
\hline \multirow[b]{2}{*}{ Synoptic event } & \multirow{2}{*}{$\begin{array}{c}\text { Date } \\
(\mathrm{d} / \mathrm{m} / \mathrm{yr})\end{array}$} & \multirow{2}{*}{$\begin{array}{c}\text { Mean } \\
\text { wind } \\
\text { speed } \\
\left(\mathrm{m} \mathrm{s}^{-1}\right)\end{array}$} & \multirow{2}{*}{$\begin{array}{c}\text { Mean } \\
\text { wind } \\
\text { stress } \\
(\mathrm{Pa})\end{array}$} & \multicolumn{2}{|c|}{$\begin{array}{c}A_{z} \\
\left(\mathrm{~m}^{2} \mathrm{~s}^{-1}\right)\end{array}$} & \multicolumn{2}{|c|}{$\begin{array}{c}W_{a d} \\
\left(\mathrm{~m}^{2} \mathrm{~s}^{-1}\right)\end{array}$} & \multicolumn{2}{|c|}{$\begin{array}{l}D_{E} \\
(\mathrm{~m})\end{array}$} \\
\hline & & & & Mean & Max. & Mean & Max. & Mean & Max. \\
\hline Cold front & $07 / 11 / 2004$ & 8.7 & 0.12 & $10.7 \times 10^{-3}$ & $23.1 \times 10^{-3}$ & $0.18 \times 10^{-3}$ & $1.8 \times 10^{-3}$ & 63 & 103 \\
\hline Tropical wave & $04 / 07 / 2005$ & 9.4 & 0.15 & $12.9 \times 10^{-3}$ & $33.0 \times 10^{-3}$ & $0.35 \times 10^{-3}$ & $4.8 \times 10^{-3}$ & 67 & 115 \\
\hline Low-pressure system & $05 / 10 / 2005$ & 6.3 & 0.07 & $6.5 \times 10^{-3}$ & $45.5 \times 10^{-3}$ & $0.20 \times 10^{-3}$ & $7.8 \times 10^{-3}$ & 46 & 135 \\
\hline Hurricane Ivan & $13 / 09 / 2004$ & 68.5 & 15.70 & 0.058 & 0.64 & 0.018 & 8.4 & 138 & 506 \\
\hline Hurricane Wilma & $20 / 10 / 2005$ & 57.6 & 11.10 & 0.053 & 0.45 & 0.017 & 5.4 & 140 & 440 \\
\hline
\end{tabular}

events showed heavy cloud cover. In the days following the passage of the cold front over the Yucatan Basin, around 7 November 2004 (fig. 4a), chl- $a$ concentrations throughout the basin rose to mean levels between 0.08 and $0.12 \mathrm{mg} \mathrm{m}^{-3}$ (fig. 6a, b). Maximum concentrations $\left(\sim 0.38 \mathrm{mg} \mathrm{m}^{-3}\right)$ were observed in a $\sim 50-\mathrm{km}$-long chl- $a$ filament that appeared south of the San Felipe keys (Gulf of Batabanó, southwest Cuba) (fig. 6a). A longer filament of $120 \mathrm{~km}$ was observed extending south of Cape San Antonio, Cuba (fig. 6a), advected around a small cyclonic eddy centered about $21.5^{\circ} \mathrm{N}, 85^{\circ} \mathrm{W}$ (white box in fig. 6b). Filaments of high chl- $a$ $\left(0.12-0.35 \mathrm{mg} \mathrm{m}^{-3}\right)$ were observed off the southwest corner of Cuba (fig. 6c) after the easterly tropical wave moved through the region on 3 July 2005 (fig. 4b). Another area with high chl- $a$ concentrations $\left(0.20-0.25 \mathrm{mg} \mathrm{m}^{-3}\right)$ was observed in the southwestern Yucatan Basin. Basin-wide increases in chl- $a$ were evident $\left(0.07-0.12 \mathrm{mg} \mathrm{m}^{-3}\right.$, fig. 6d) after the low-pressure system crossed the Yucatan Basin around 6 October 2005 (fig. 4c). A filament $\left(\sim 1.4 \mathrm{mg} \mathrm{m}^{-3}\right)$ of $\sim 300 \mathrm{~km}$ length and $50 \mathrm{~km}$ width extended south of San Felipe Keys (Cuba) to Cayman Island. A shorter filament was observed again off Cape San Antonio (western Cuba) during this event.

On 11 September 2004, two days before Hurricane Ivan passed through the Yucatan Basin, chl- $a$ concentrations were low $\left(\sim 0.03 \mathrm{mg} \mathrm{m}^{-3}\right)$ (fig. 7a). On 20 September 2004, one week after Hurricane Ivan passed over southern Cuba, filaments and patches were observed in the center of the Yucatan Basin (fig. 7b). Several filaments extended northward, into the Gulf of Mexico, from the Gulf of Guanahacabibes (western Cuba), and to the east and southwest of Pinos Island (southwestern Cuba, fig. 7b). High concentrations were observed on 25 October 2005 (fig. 7d), five days after Hurricane Wilma (fig. 5c) passed through the Yucatan Basin. Along the track of Hurricane Wilma, chl-a concentrations exceeded $1.0 \mathrm{mg} \mathrm{m}^{-3}$ in the western Yucatan Basin and particularly in the upwelling area off the northern Yucatan regional anual (fig. 2), y refleja el poder de mezcla de los huracanes.

Durante el huracán Wilma (categoría 4), la mezcla causada por el viento y el bombeo de Ekman fueron similares. $W_{a d}\left(5.4 \mathrm{~m}^{2} \mathrm{~s}^{-1}\right)$ fue un orden de magnitud mayor que $A_{\mathrm{z}}$ $\left(0.45 \mathrm{~m}^{2} \mathrm{~s}^{-1}\right)$ cuando Wilma pasó por la cuenca de Yucatán, con velocidades máximas de $57.6 \mathrm{~m} \mathrm{~s}^{-1}$ y un esfuerzo máximo del viento de $11.1 \mathrm{~Pa}$ (fig. 5c, d; tabla 2). Al igual que el huracán Iván, los valores máximos de $W_{a d}$ y $A_{z}$ se registraron en un área de $\sim 100 \times 100 \mathrm{~km} \mathrm{y} \sim 300 \times 300 \mathrm{~km}$, respectivamente, alrededor del ojo del huracán (insertos fig. 5a, c).

La $D_{E}$ alcanzó valores máximos de $103 \mathrm{~m}$ durante el frente frío, de $115 \mathrm{~m}$ durante la onda tropical del este y de $135 \mathrm{~m}$ durante el sistema de baja presión. La $D_{E}$ más profunda se observó alrededor de los ojos de los huracanes Iván y Wilma, a 505 y $440 \mathrm{~m}$, respectivamente (no se muestra la figura). Ambos valores fueron registrados del lado derecho del ojo de los huracanes. Estos valores fueron sobreestimados porque no se consideró la estabilidad de la columna de agua en los cálculos.

\section{Respuesta de la clorofila $a$}

Las imágenes satelitales de la concentración de clorofila $a$ obtenidas durante y después del paso de estos eventos meteorológicos mostraron una fuerte nubosidad. En los días después del paso del frente frío sobre la cuenca de Yucatán, alrededor del 7 de noviembre de 2004 (fig. 4a), las concentraciones de clorofila $a$ aumentaron a niveles de entre $0.08 \mathrm{y}$ $0.12 \mathrm{mg} \mathrm{m}^{-3}$ (fig. 6a, b). Las concentraciones máximas $\left(\sim 0.38 \mathrm{mg} \mathrm{m}^{-3}\right)$ se registraron en un filamento de clorofila $a$ de $\sim 50 \mathrm{~km}$ de largo que apareció al sur de los cayos de San Felipe (golfo de Batabanó, suroeste de Cuba) (fig. 6a). Se detectó un filamento más largo, de $120 \mathrm{~km}$, al sur de Cabo San Antonio, Cuba (fig. 6a), alrededor de un giro ciclónico pequeño centrado en $21.5^{\circ} \mathrm{N}, 85^{\circ} \mathrm{W}$ (cuadro blanco en 


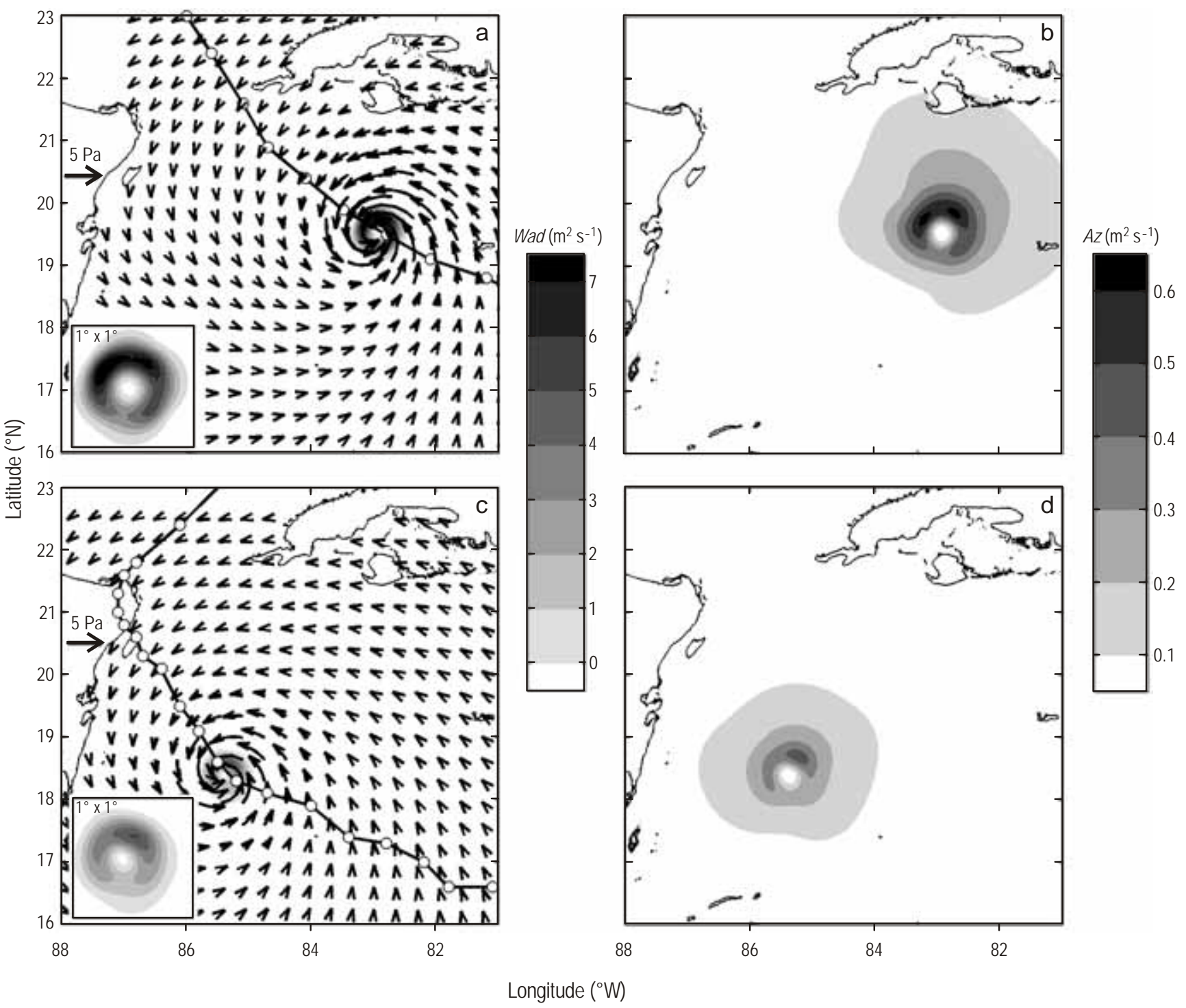

Figure 5. Vertical transport $\left(W_{a d}\right)$ and eddy viscosity or friction coefficient $\left(A_{z}\right)$ during extreme meteorological events: (a, b) position of category 5 Hurricane Ivan at 0130 UTC on 13 September 2004; (c, d) position of category 4 Hurricane Wilma at 1330 UTC on 20 October 2005. (a, c) Black arrows denote wind stress vectors ( $\mathrm{Pa}$, a reference vector, is plotted on the Yucatan Peninsula); black lines with white circles correspond to the 6 -h best-track positions of the hurricanes; the square inlay in the lower left corner represents a $1^{\circ} \times 1^{\circ}$ zoom of maximum $W_{a d}$ values around the eye of the hurricanes.

Figura 5. Transporte vertical $\left(W_{a d}\right)$ y viscosidad de remolino o coeficiente de fricción $\left(A_{z}\right)$ durante eventos meteorológicos extremos: (a, b) posición del huracán Iván (categoría 5) a 0130 UTC el 13 de septiembre de 2004; (c, d) posición del huracán Wilma (categoría 4) a 1330 UTC el 20 de octubre de 2005. (a, c) Las flechas negras indican los vectores del esfuerzo del viento (Pa, un vector de referencia, se muestra para la península de Yucatán); las líneas negras con círculos blancos corresponden a las posiciones de la trayectoria de los huracanes en intervalos de $6 \mathrm{~h}$; el inserto en la parte inferior izquierda representa un acercamiento de $1^{\circ} \times 1^{\circ}$ de los valores máximos de $W_{a d}$ alrededor del ojo de los huracanes.

Peninsula in the Gulf of Mexico. Some of these patterns persisted seven days after the hurricane passed (fig. 7e). The regions with high chl- $a$ values coincided with areas of sea surface cooling, showing that water was mixed from the subsurface to the surface in the hurricane trail (supplement 2, inferior panel). fig. 6b). Se observaron concentraciones altas de clorofila $a$ $\left(0.12-0.35 \mathrm{mg} \mathrm{m}^{-3}\right)$ en forma de filamentos al suroeste de Cuba (fig. 6c) después del paso de la onda tropical del este el 3 de julio de 2005 (fig. 4b). Se observó otra zona con concentraciones altas de clorofila $a\left(0.20-0.25 \mathrm{mg} \mathrm{m}^{-3}\right)$ en la parte suroeste de la cuenca de Yucatán. Fue evidente el aumento en 


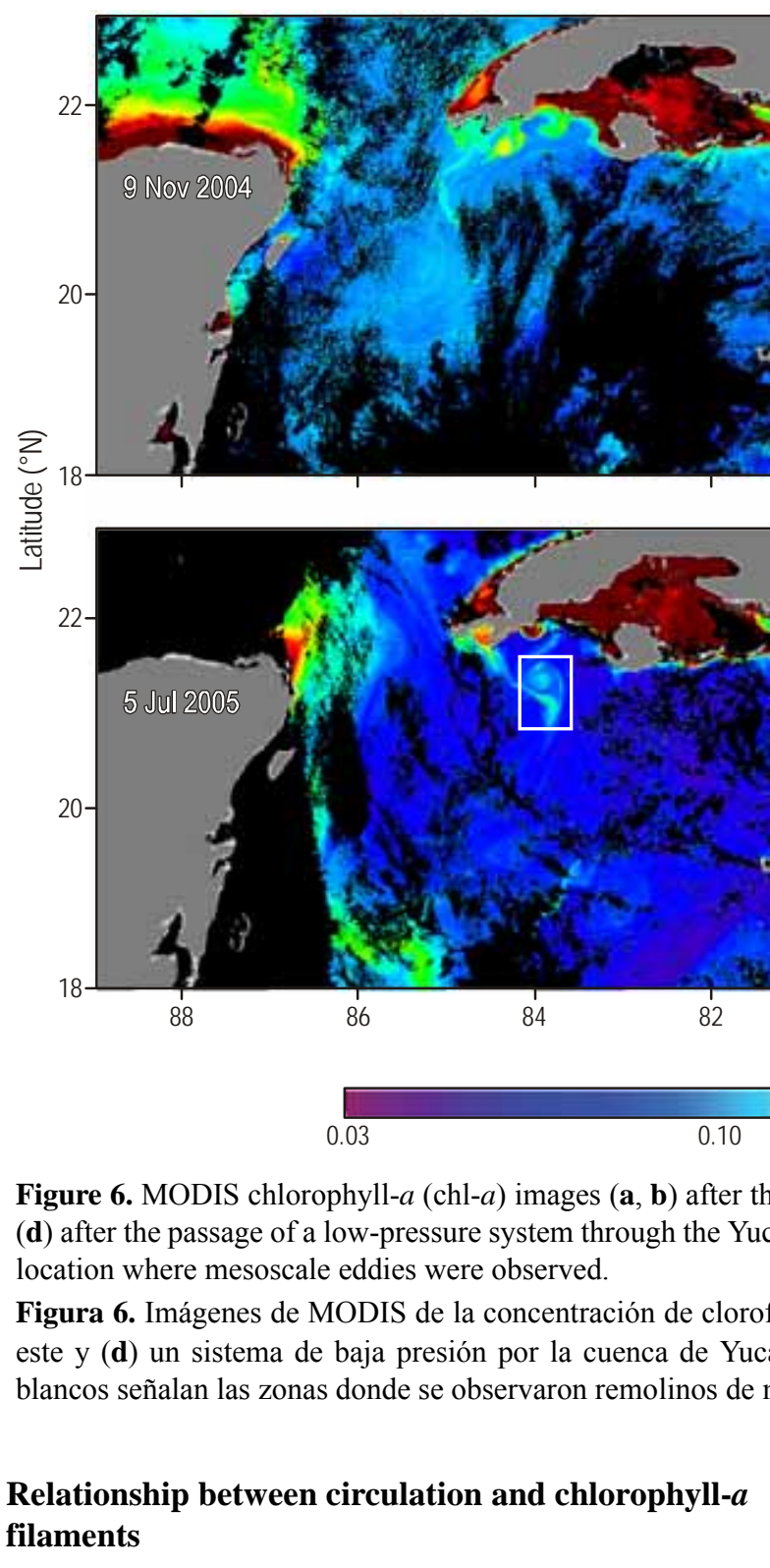

Sea surface currents were analyzed in order to understand the trajectories of chl- $a$ filaments observed in the Yucatan Basin using weekly geostrophic current products derived from satellite altimeter data merged with concurrent chl- $a$ images (fig. 8). Figure 8a shows a group of eddies: one anticyclonic $\left(20.0^{\circ} \mathrm{N}, 86.0^{\circ} \mathrm{W}\right)$, one cyclonic $\left(20.6^{\circ} \mathrm{N}, 84.3^{\circ} \mathrm{W}\right)$, and another anti-cyclonic $\left(\sim 20.0^{\circ} \mathrm{N}, 82.0^{\circ} \mathrm{W}\right)$. These eddies can advect coastal water into the central Yucatan Basin, as observed on multiple dates in figure 8 .

\section{DISCUSSION}

The MODIS chl- $a$ images highlight patterns of variability and connectivity associated with different types of meteorological events. One pattern was related to the passage of moderate synoptic events (i.e., cold front, low-pressure
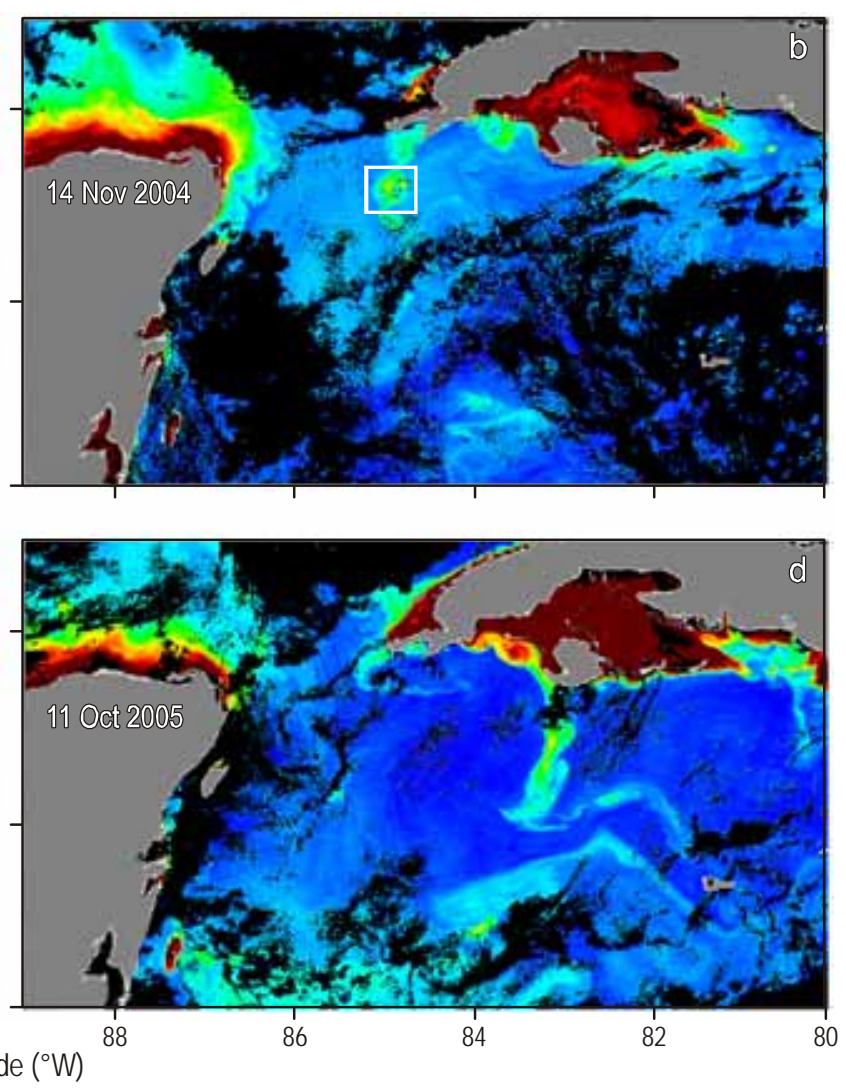

Longitude $\left({ }^{\circ} \mathrm{W}\right)$

Chl- $a\left(\mathrm{mg} \mathrm{m}^{-3}\right)$

0.20

0.50

1.00

1.50 

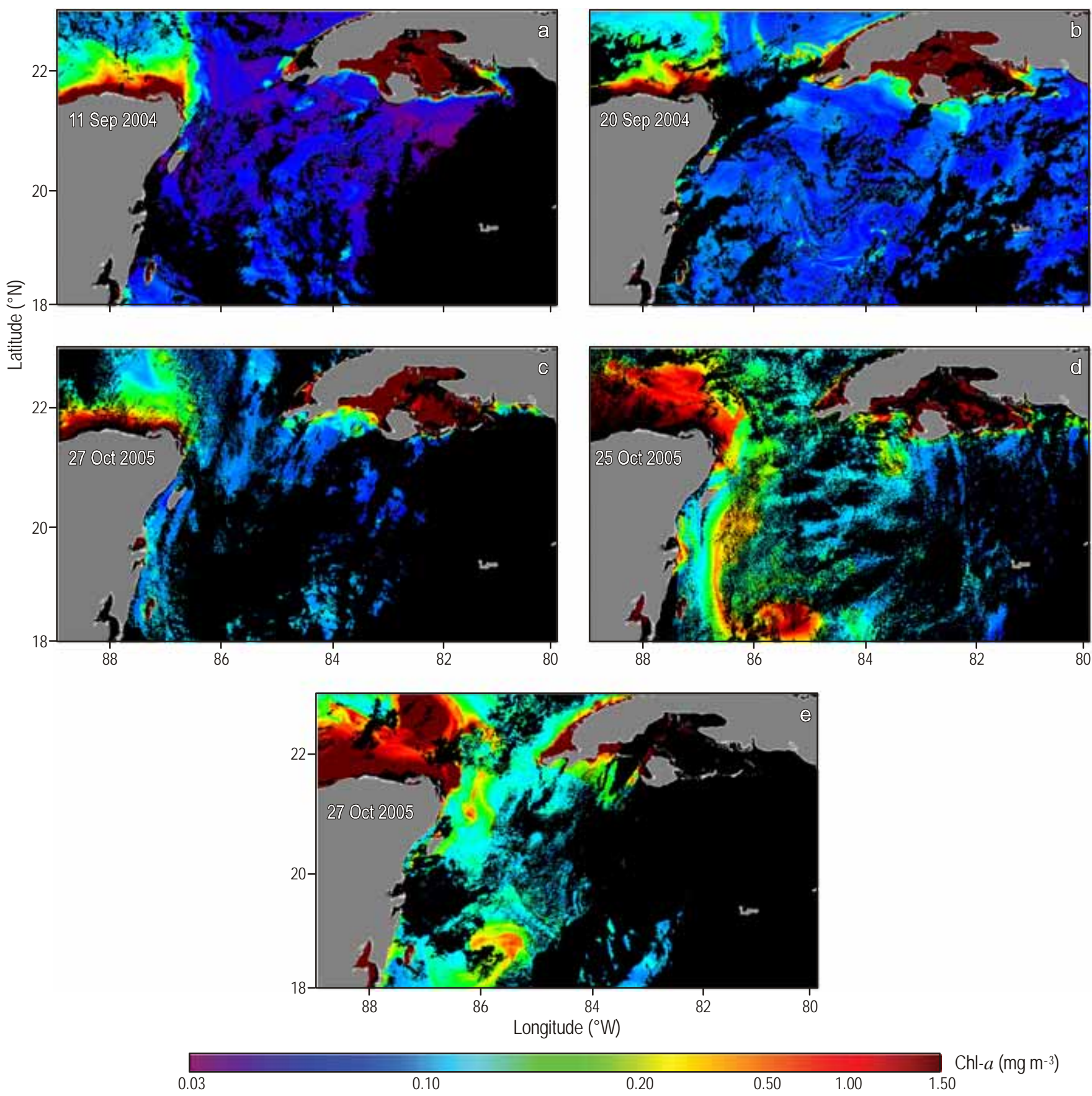

Figure 7. MODIS chlorophyll $a$ (chl- $a$ ) images (a) before and (b) after the passage of Hurricane Ivan, and (c) before and (d, e) after the passage of Hurricane Wilma through the Yucatan Basin. Black regions represent no data (clouds).

Figura 7. Imágenes de MODIS de la concentración de clorofila $a$ (chl-a) (a) antes y (b) después del paso del huracán Iván, y (c) antes y (d, e) después del paso del huracán Wilma por la cuenca de Yucatán. Las regiones negras indican que no hay datos (nubosidad).

system, and easterly tropical wave). Increased chl- $a$ concentrations $\left(0.03-0.12 \mathrm{mg} \mathrm{m}^{-3}\right)$ were observed throughout the Yucatan Basin, with local extremes up to $0.40 \mathrm{mg} \mathrm{m}^{-3}$ for periods of about a week. Extreme events (hurricanes Ivan, September 2004, and Wilma, October 2005) showed a different pattern, with high regional chl- $a$ concentrations up to $2.0 \mathrm{mg} \mathrm{m}^{-3}$ in concentrated patches and filaments lasting del huracán Wilma (fig. 5c) por la cuenca de Yucatán. A lo largo de la trayectoria de Wilma, las concentraciones de clorofila $a$ excedieron $1.0 \mathrm{mg} \mathrm{m}^{-3}$ en la parte oeste de la cuenca y especialmente en la zona de surgencias al norte de la península de Yucatán en el golfo de México. Algunos de estos patrones persistieron siete días después del paso del huracán (fig. 7e). Las regiones con valores altos de clorofila $a$ 
between two days and one week. Another recurring pattern was the chl-a-rich filaments extending from the western coast of Cuba to either the south or the north of the Gulf of Mexico (figs. 6, 7).

The Yucatan Basin was considered to be an oligotrophic region whose surface layer was nutrient-depleted (Okolodkov 2003). During meteorological events, the supply of nutrients from below occurred with positive vertical transport $\left(W_{a d}\right)$ and vertical eddy viscosity $\left(A_{z}\right)$ (figs. $\left.2,4,5\right)$. $A_{z}$ was high during the influence of moderate events $(10 \times$ $10^{-3} \mathrm{~m}^{2} \mathrm{~s}^{-1}$ ), with a deepening of the mixed layer to more than $100 \mathrm{~m}$. A positive vertical transport caused by wind stress curl was also observed, although this was one order of magnitude lower than wind-induced eddy diffusivity. During extreme meteorological events, this condition reversed, and upward vertical transport was high $\left(5-7 \mathrm{~m}^{2} \mathrm{~s}^{-1}\right)$ in the vicinity of the eye of hurricanes Ivan and Wilma (fig. 5), and eddy diffusivity was lower. Measurements made with current meters show that vertical mixing due to these extreme storm events can extend to a depth of $1000 \mathrm{~m}$ (Shay 2001).

Several chl- $a$ filaments extended seaward from coastal areas in the region, some extending out to 50 and $300 \mathrm{~km}$ (figs. 6, 7). River discharge can transport terrigenous material into any of the embayments around the periphery of the Yucatan Basin. The Gulf of Batabanó, for example, accumulated sediments after rainfall north of the San Felipe keys (Blázquez et al. 1988). The chl-a filaments originating in this area were steered by the wind and local oceanic currents (fig. 8, supplement 1). These patterns contribute to the connectivity network of fish larvae in the wider Caribbean (Cowen et al. 2006).

The vertical eddy diffusivity $\left(K_{v}\right)$ computations using temperature, salinity, and meridional and zonal velocity profiles from the MERCATOR assimilation model included the contribution of vertical shear $\left(S^{2}\right)$ to mixing of the water column (fig. 3). A shear layer was detected near the mixed layer depth with low gradient Richardson numbers $(R i)$. Ri values of $\sim 0.25$ were observed in an area influenced by the Yucatan Current (supplement 1), indicating that shear instabilities can occur (Muench et al. 2002). On the other hand, Ri values of $\sim 1$ were observed off southern Cuba. Here, the Cuban countercurrent and mesoecale eddies may favor advective instabilities (Muench et al. 2002). The combination of mixing by surface winds (wind stress and Ekman pumping) and currents (shear) allowed the injection of nutrients from the subsurface layer, increasing the chl- $a$ concentrations in the Yucatan basin.

In summary, vertical advective transport (Ekman pumping) and turbulent diffusive transport (eddy viscosity) induced by wind stress curl and wind stress during moderate and extreme synoptic meteorological events favored increased levels of chl- $a$ in the otherwise oligotrophic Yucatan Basin. Although these mechanisms act together, turbulent diffusive transport was higher during moderate coincidieron con áreas del océano que muestran enfriamiento de aguas superficiales, lo cual indica la mezcla de agua de la subsuperficie a la superficie en la trayectoria del huracán (suplemento 2, panel inferior).

\section{Relación entre la circulación y los filamentos de clorofila $a$}

Para entender las trayectorias de los filamentos de clorofila $a$ observados en la cuenca de Yucatán, se analizaron las corrientes superficiales del mar mediante productos semanales de las corrientes geostróficas derivados de datos proporcionados por altímetros satelitales combinados con imágenes concurrentes de clorofila $a$ (fig. 8). La figura 8a muestra un grupo de remolinos: uno anticiclónico $\left(20.0^{\circ} \mathrm{N}, 86.0^{\circ} \mathrm{W}\right)$, uno ciclónico $\left(20.6^{\circ} \mathrm{N}, 84.3^{\circ} \mathrm{W}\right)$, y otro anticiclónico $\left(\sim 20.0^{\circ} \mathrm{N}, 82.0^{\circ} \mathrm{W}\right)$. Los remolinos pueden transportar agua costera a la parte central de la cuenca de Yucatán, como se observa en varias fechas en la figura 8 .

\section{Discusión}

Las imágenes de clorofila $a$ del sensor MODIS evidencian patrones de variabilidad y conectividad asociados con los diferentes tipos de fenómenos meteorológicos de escala sinóptica. Un patrón se relacionó con el paso de eventos moderados (i.e., frente frío, sistema de baja presión y onda tropical del este). Las concentraciones de clorofila $a$ aumentaron en toda la cuenca de Yucatán $\left(0.03-0.12 \mathrm{mg} \mathrm{m}^{-3}\right)$, con extremos locales de hasta $0.40 \mathrm{mg} \mathrm{m}^{-3}$ durante periodos de alrededor de una semana. Los eventos extremos (huracanes Iván, septiembre de 2004, y Wilma, octubre de 2005) mostraron un patrón diferente, con concentraciones regionales de clorofila $a$ de hasta $2.0 \mathrm{mg} \mathrm{m}^{-3}$ en ciertos parches y filamentos que duraron de dos días a una semana. Otro patrón recurrente fue la extensión de filamentos ricos en clorofila $a$ de la costa oeste de Cuba hacia ya sea el sur o norte del golfo de México (figs. 6, 7).

La cuenca de Yucatán ha sido descrita como una región oligotrófica carente de nutrientes en la capa superficial (Okolodkov 2003). Durante los eventos meteorológicos, el aporte de nutrientes de abajo se dio con transporte vertical positivo $\left(W_{a d}\right)$ y viscosidad vertical de remolino $\left(A_{z}\right)$ (figs. 2, 4, 5). La $A_{z}$ fue alta durante la influencia de los eventos moderados $\left(10 \times 10^{-3} \mathrm{~m}^{2} \mathrm{~s}^{-1}\right)$, con una profundización de la capa de mezcla hasta más de $100 \mathrm{~m}$. También se observó un transporte vertical positivo debido al rotacional del esfuerzo del viento, aunque fue un orden de magnitud menor que la difusividad de remolino inducida por el viento. Durante los eventos meteorológicos extremos, esta condición se invirtió, y el transporte vertical advectivo fue alto $\left(5-7 \mathrm{~m}^{2} \mathrm{~s}^{-1}\right)$ cerca del ojo de los huracanes Iván y Wilma (fig. 5), y la difusividad de remolino fue menor. Mediciones realizadas con correntómetros muestran que la mezcla vertical debido a estos eventos extremos puede alcanzar los $1000 \mathrm{~m}$ de profundidad (Shay 2001). 

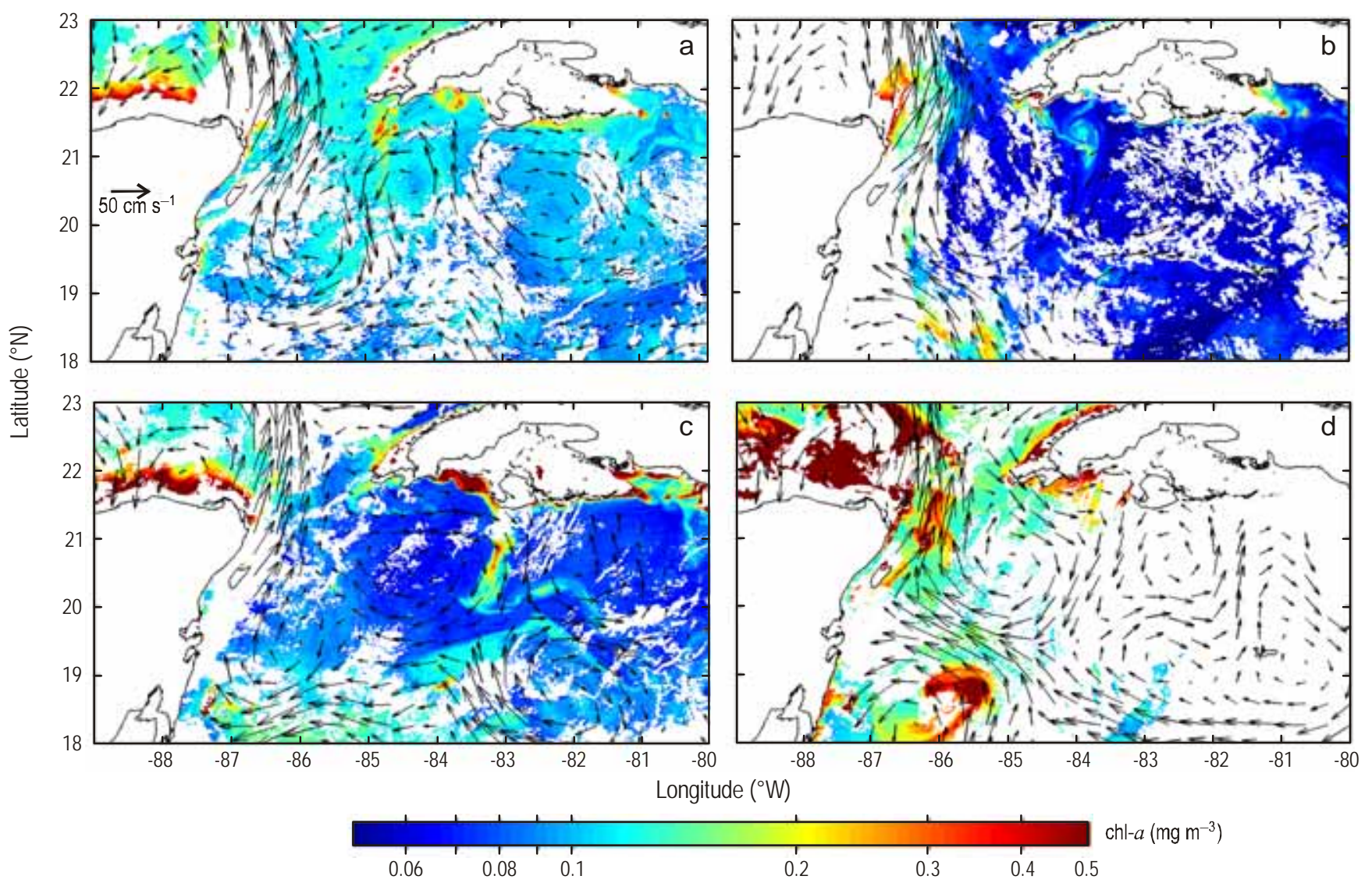

Figure 8. MODIS chlorophyll $a$ (chl-a) images after the passage of synoptic-scale meteorological events and corresponding weekly mean geostrophic currents (black arrows) from the AVISO altimeter. (a) Cold front (13 November 2004), (b) easterly tropical wave (5 July 2005 ), (c) low-pressure system (11 October 2005), and (d) Hurricane Wilma (27 October 2005).

Figura 8. Imágenes de MODIS de las concentraciones de clorofila $a$ (chl- $a$ ) después del paso de eventos meteorológicos de escala sinóptica y las correspondientes corrientes geostróficas semanales promedio (flechas negras) del altímetro AVISO. (a) Frente frío (13 de noviembre de 2004), (b) onda tropical del este (5 de julio de 2005), (c) sistema de baja presión (11 de octubre de 2005) y (d) huracán Wilma (27 de octubre de 2005).

events, whereas vertical advective transport became dominant during extreme events. Low Ri values were observed on the western side of the Yucatan Basin due to the influence and variability of the Yucatan Current, suggesting that vertical shear instabilities in the flow can enhance mixing in the water column. The three-dimensional data of the MERCATOR assimilation model proved to be a helpful tool to study the temporal and spatial variability of mixing processes in the Yucatan Basin.

The presence of high chl- $a$ concentrations in the form of filaments after the passage of synoptic-scale meteorological events, combined with increased precipitation on the Cuban island, demonstrated the importance of terrestrial nutrient sources, including inorganic fertilizers, for phytoplankton blooms in the Gulf of Batabanó, Cuba. The direction and magnitude of the ocean currents determined the dispersion and the trajectories of these filaments, contributing to the connectivity in the northwestern Caribbean Sea.
Varios filamentos de clorofila $a$ se extendieron de las zonas costeras hacia mar adentro, algunos por más de $50 \mathrm{y}$ $300 \mathrm{~km}$ (figs. 6, 7). Las descargas de ríos pueden transportar material terrígeno a cualquier bahía en la periferia de la cuenca de Yucatán. El golfo de Batabanó, por ejemplo, acumuló sedimentos después de que lloviera al norte de los cayos de San Felipe (Blázquez et al. 1988). Los filamentos de clorofila $a$ que se originaron en esta zona fueron dirigidos por el viento y las corrientes oceánicas locales (fig. 8, suplemento 1). Estos patrones contribuyen a la red de conectividad de las larvas de peces en todo el Caribe (Cowen et al. 2006).

Los cálculos de la difusividad vertical de remolino $\left(K_{v}\right)$ con datos de temperatura, salinidad y los perfiles de velocidad zonal y meridional del modelo de asimilación MERCATOR incluyeron la contribución de la cizalladura vertical $\left(S^{2}\right)$ a la mezcla de la columna de agua (fig. 3). Se detectó una capa de cizalladura cerca de la profundidad de la capa de mezcla con números de Richardson (Ri) bajos. Se observaron valores de $R i$ de $\sim 0.25$ en la zona influenciada por 


\section{ACKNOWLEDGMENTS}

Thanks are due to the National Commission for Scientific and Technological Research (CONICYT, Chile) for providing a doctorate scholarship for IPS (2006330027-6) to study at the University of Concepción, Chile, and to the MECESUP Program for supporting a research stay at AOML-NOAA, Miami, University of South Florida and University of Florida. AVL acknowledges support from the National Science Foundation (project OCE-0825876). FMK received support from NASA grants NNX09AV24G and NNX08AL06G. The authors also thank CONICYTFONDECYT (grant 3120038), COPAS Sur Austral (grant PFB 31/2007), and the anonymous reviewers.

\section{REFERENCES}

Babin SM, Carton JA, Dickey TD, Wiggert JD. 2004. Satellite evidence of hurricane-induced phytoplankton blooms in an oceanic desert. J. Geophys. Res. 109(C3). http://dx.doi.org/10.1029/2003jc001938

Blázquez L, Rodríguez JP, Rosabal I, Calderón R. 1988. Mediciones de corrientes en el Golfo de Batabanó. Rep. Invest. Inst. Oceanol. Acad. Cienc. Cuba 14: 1-36.

Centurioni LR, Niiler PP. 2003. On the surface currents of the Caribbean Sea. Geophys. Res. Lett. 30(6). http://dx.doi.org/10.1029/2002g1016231

Cowen RK, Paris CB, Srinivasan A. 2006. Scaling of connectivity in marine populations. Science 311(5760): 522-527. http://dx.doi.org/10.1126/science.1122039

Donelan MA, Haus BK, Reul N, Plant WJ, Stiassnie M, Graber HC, Brown OB, Saltzman ES. 2004. On the limiting aerodynamic roughness of the ocean in very strong winds. Geophys. Res. Lett. 31(18). http://dx.doi.org/10.1029/2004g1019460

González NM, Müller-Karger FE, Estrada SC, Pérez De Los Reyes R, Del Río IV, Pérez PC, Arenal IM. 2000. Near-surface phytoplankton distribution in the western Intra-Americas Sea: The influence of El Niño and weather events. J. Geophys. Res. 105(C6): 14029-14043. http://dx.doi.org/10.1029/2000jc900017

González PC. 1999. Climatología de los frentes fríos que han afectado a Cuba desde 1916-1917 hasta 1996-1997. Rev. Cub. Meteorol. 6: 15-19.

Johns WE, Townsend TL, Fratantoni DM, Wilson WD. 2002. On the Atlantic inflow to the Caribbean Sea. Deep-Sea Res. I 49: 211-243. http://dx.doi.org/10.1016/S0967-0637(01)00041-3

Jouanno J, Sheinbaum J, Barnier B, Molines JM, Debreu L, Lemarie F. 2008. The mesoscale variability in the Caribbean Sea. Part I: Simulations and characteristics with an embedded model. Ocean Model. 23: 82-101. http://dx.doi.org/10.1016/j.ocemod.2008.04.002

Letelier RM, Abbott MR. 1996. An analysis of chlorophyll fluorescence algorithms for the moderate resolution imaging spectrometer (MODIS). Remote Sens. Environ. 58: 215-223. http://dx.doi.org/10.1016/S0034-4257(96)00073-9

Locarnini RA, Mishonov AV, Antonov JI, Boyer TP, Garcia HE, Baranova OK, Zweng MM, Johnson DR. 2010. World Ocean Atlas 2009. Volume 1: Temperature. In: Levitus S (ed.), NOAA Atlas NESDIS 68, US Government Printing Office, Washington DC, 184 pp. la corriente de Yucatán (suplemento 1), lo que indica que pueden suceder inestabilidades de cizalladura (Muench et al. 2002). Por otro lado, se observaron valores de $R i$ de $\sim 1$ al sur de Cuba. Aquí, la contracorriente cubana y los remolinos de mesoescala pueden favorecer inestabilidades advectivas (Muench et al. 2002). La combinación de mezcla por vientos superficiales (esfuerzo del viento y bombeo de Ekman) y corrientes (cizalladura) permitió la inyección de nutrientes de la capa subsuperficial, incrementando las concentraciones de clorofila $a$ en la cuenca de Yucatán.

En resumen, el transporte vertical advectivo (bombeo de Ekman) y el transporte difusivo turbulento (viscosidad de remolino), inducidos por el esfuerzo del viento y su rotacional durante eventos meteorológicos moderados y extremos de escala sinóptica, favorecieron el incremento de los niveles de clorofila $a$ en la oligotrófica cuenca de Yucatán. Aunque estos mecanismos actúan en conjunto, el transporte difusivo turbulento fue mayor durante los eventos moderados, mientras que el transporte vertical advectivo dominó durante los eventos extremos. Se registraron valores de Ri bajos del lado oeste de la cuenca de Yucatán debido a la influencia y variabilidad de la corriente de Yucatán, lo que sugiere que inestabilidades de cizalladura vertical en el flujo pueden incrementar la mezcla en la columna de agua. Los datos tridimensionales del modelo de asimilación MERCATOR resultaron ser una herramiento útil para estudiar la variabilidad temporal y espacial de los procesos de mezcla en la cuenca de Yucatán.

La presencia de concentraciones altas de clorofila $a$ en forma de filamentos después del paso de eventos meteorológicos de escala sinóptica, en conjunto con un incremento de la precipitación en la isla de Cuba, mostró la importancia de las fuentes terrestres de nutrientes, incluyendo los fertilizantes inorgánicos, para los afloramientos de fitoplancton en el golfo de Batabanó, Cuba. La dirección y magnitud de las corrientes oceánicas determinó la dispersión y las trayectorias de estos filamentos, contribuyendo a la conectividad en el mar Caribe noroccidental.

\section{Agradecimientos}

Se agradece a la Comisión Nacional de Investigación Científica y Tecnológica (CONICYT, Chile) la beca otorgada a IPS (2006330027-6) para realizar estudios doctorales en la Universidad de Concepción, Chile, y al programa MECESUP su apoyo para una estancia en AOML-NOAA, Miami, Universidad del Sur de Florida y Universidad de Florida. AVL agradece el apoyo de la Fundación Nacional de la Ciencia (NSF) de los Estados Unidos (proyecto OCE0825876). FMK reconoce el apoyo recibido de la NASA (NNX09AV24G y NNX08AL06G). También se agradece a CONICYT-FONDECYT (proyecto 3120038) y COPAS Sur Austral (proyecto PFB 31/2007), así como a los revisores anónimos.

Traducido al español por Christine Harris. 
Lorbacher K, Dommenget D, Niiler PP, Kohl A. 2006. Ocean mixed layer depth: A subsurface proxy of ocean-atmosphere variability. J. Geophys. Res. 111(C7). http://dx.doi.org/10.1029/2003jc002157

Marcotte D. 1991. Cokriging with Matlab. Comput. Geosci. 17: $1265-1280$. http://dx.doi.org/10.1016/0098-3004(91)90028-C

McClain CR. 2009. A decade of satellite ocean color observations. Annu. Rev. Mar. Sci. 1: 19-42. http://dx.doi.org/10.1146/annurev.marine.010908.163650

Muench RD, Padman L, Howard SL, Fahrbach E. 2002. Upper ocean diapycnal mixing in the northwestern Weddell Sea. DeepSea Res. II 49: 4843-4861. http://dx.doi.org/10.1016/S0967-0645(02)00162-5

Müller-Karger FE, Walsh JJ, Evans RH, Meyers MB. 1991. On the seasonal phytoplankton concentration and sea surface temperature cycles of the Gulf of Mexico as determined by satellites. J. Geophys. Res. 96(C7): 12645-12665. http://dx.doi.org/10.1029/91jc00787

Okolodkov YB. 2003. A review of Russian plankton research in the Gulf of Mexico and the Caribbean Sea in the 1960-1980s. Hidrobiológica 13: 207-221. http://www.redalyc.org/articulo.oa?id=57813306

Peláez JA, McGowan J. 1986. Phytoplankton pigment patterns in the California Current as determined by satellite. Limnol. Oceanogr. 31: 927-950. http://dx.doi.org/10.4319/1o.1986.31.5.0927

Pérez-Santos I, Schneider W, Sobarzo M, Montoya-Sánchez R, Valle-Levinson A, Garcés-Vargas J. 2010. Surface wind variability and its implications for the Yucatan Basin-Caribbean Sea dynamics. J. Geophys. Res. 115. http://dx.doi.org/10.1029/2010jc006292
Pond S, Pickard GL. 1983. Introductory Dynamical Oceanography. Pergamon Press, Oxford, 329 pp.

Rodríguez-Santana A, Pelegrí JL, Sangra P, Marrero-Díaz A. 1999. Diapycnal mixing in Gulf Stream meanders. J. Geophys. Res. 104(C11): 25891-25912. http://dx.doi.org/10.1029/1999jc900219

Romanou A, Chassignet EP, Sturges W. 2004. Gulf of Mexico circulation within a high-resolution numerical simulation of the North Atlantic Ocean. J. Geophys. Res. 109(C1). http://dx.doi.org/10.1029/2003jc001770

Shay LK. 2001. Upper ocean structure: Response to strong forcing events. In: Steele J, Thorpe S, Turekian K (eds.), Encyclopedia of Ocean Science. Academic Press, London, pp. 3100-3114.

Smith RL. 1968. Upwelling. In: Barnes H (ed.), Oceanography and Marine Biology. An Annual Review. George Allen and Unwin, Ltd., London, pp. 11-46.

Stewart RH. 2008. Introduction to Physical Oceanography. Department of Oceanography, Texas A \& M University, College Station, Texas, $345 \mathrm{pp}$.

Wang C, Enfield DB. 2001. The tropical Western Hemisphere warm pool. Geophys. Res. Lett. 28: 1635-1638. http://dx.doi.org/10.1029/2000gl011763

Wang C, Lee SK. 2007. Atlantic warm pool, Caribbean low-level jet, and their potential impact on Atlantic hurricanes. Geophys. Res. Lett. 34(2). http://dx.doi.org/10.1029/2006gl028579

Yelland M, Taylor PK. 1996. Wind stress measurements from the open ocean. J. Phys. Oceanogr. 26: 541-558. http://dx.doi.org/10.1175/15200485(1996)026<0541:Wsmfto $>2.0 . \mathrm{Co} ; 2$

Received June 2013, accepted December 2013.

\section{Supplementary material:}

In order to provide evidence that the MERCATOR data represented the circulation patterns of the Yucatan Basin, Caribbean Sea, a surface map is presented in supplement 1 . The results obtained with the MERCATOR model match the general circulation shown by ocean models and in situ data published for this region (e.g., Johns et al. 2002, Centurioni and Niiler 2003, Romanou et al. 2004, Jouanno et al. 2008; see text for references). Also, to confirm that deeper cold water was mixed into the surface layer during hurricane passage, sea surface temperature (SST) maps during the passage of hurricanes Ivan and Wilma are included as supplement 2. These maps are based on SST images reconstructed by optimum interpolation from the combined Advanced Microwave Scanning Radiometer and Advanced Very High Resolution Radiometer. In addition, to estimate from which depth these colder waters stem, we include vertical climatological monthly mean temperature profiles for the months corresponding to the passage of the hurricanes. Temperature data were taken from Locarnini et al. (2010).

Para proporcionar evidencia de que los datos del modelo MERCATOR representan los patrones de circulación de la cuenca de Yucatán, mar Caribe, en el suplemento 1 se presenta un mapa superficial. Los resultados obtenidos con este modelo coinciden con la circulación general que muestran modelos oceánicos y datos in situ publicados para esta región (e.g., Johns et al. 2002, Centurioni y Niiler 2003, Romanou et al. 2004, Jouanno et al. 2008; ver el texto para las referencias). Además, para confirmar que se mezcló agua profunda más fría con agua superficial durante el paso de los huracanes, se incluyen mapas de la temperatura superficial del mar (TSM) durante el paso de los huracanes Iván y Wilma (suplemento 2). Estos mapas se basan en imágenes de TSM reconstruidas mediante interpolación óptima de los sensores Advanced Microwave Scanning Radiometer y Advanced Very High Resolution Radiometer. Para estimar la profundidad de donde provinieron estas aguas frías, se incluyen perfiles verticales climatológicos de temperatura media mensual para los meses que correspondieron al paso de los huracanes. Los datos de temperatura fueron tomados de Locarnini et al. (2010). 


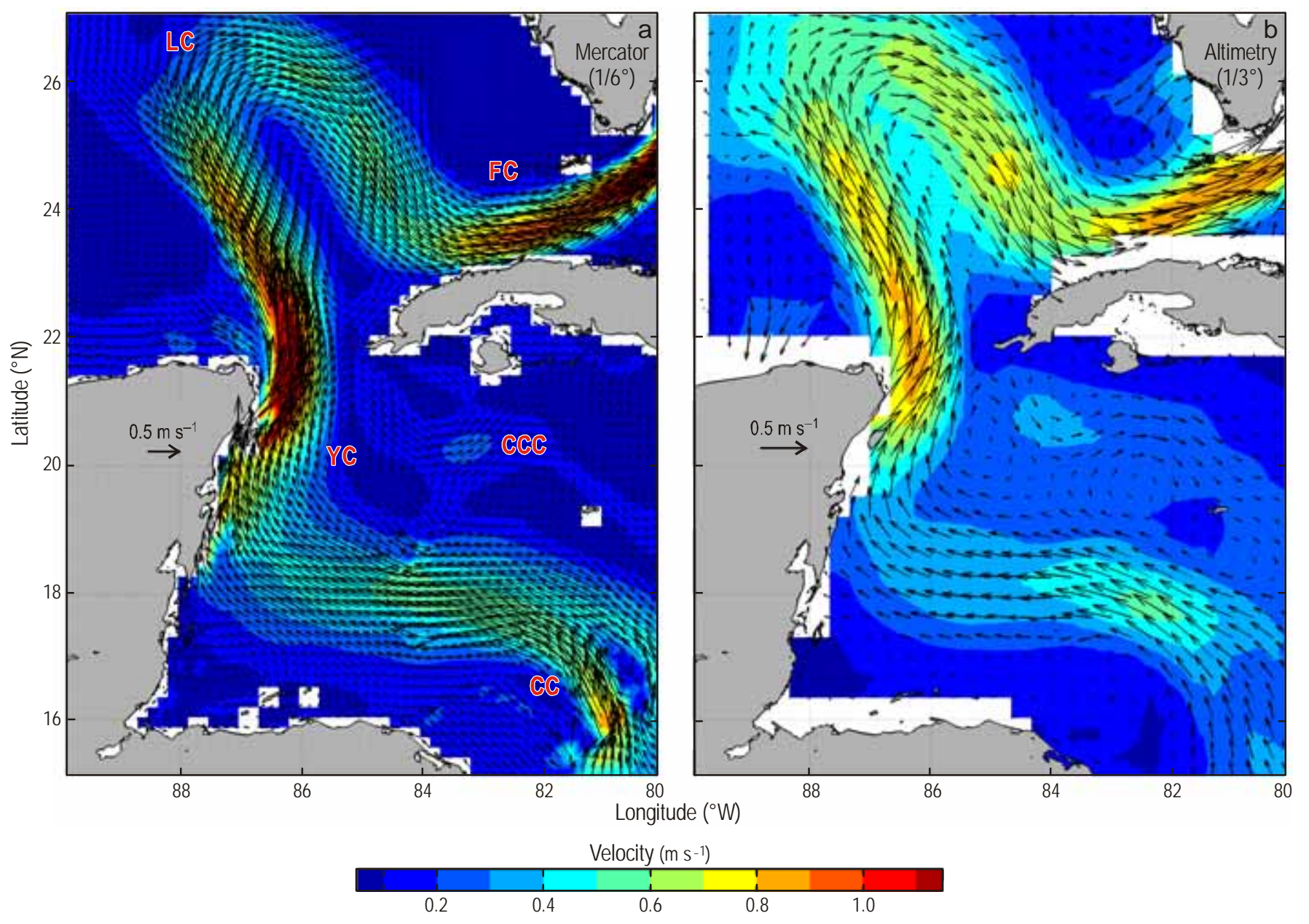

Supplement 1. Long-term mean of the surface geostrophic current systems in the Caribbean Sea and Gulf of Mexico from (a) MERCATOR and (b) AVISO data, during 2007-2009. Color contours represent the velocity field and vectors the direction of the currents. Abbreviations in panel (a): CC, Caribbean Current; YC, Yucatan Current; LC, Loop Current; FC, Florida Current; and CCC, Cuban Countercurrent.

Suplemento 1. Promedio a largo plazo de los sistemas de corrientes geostróficas superficiales en el mar Caribe y el golfo de México a partir de datos de (a) MERCATOR y (b) AVISO, durante el periodo de 2007 a 2009. Los contornos de color representan el campo de velocididad y los vectors la dirección de las corrientes. Siglas en (a): CC, corriente del Caribe; YC, corriente de Yucatán; LC, corriente de Lazo; FC, corriente de Florida; y CCC, contracorriente cubana. 

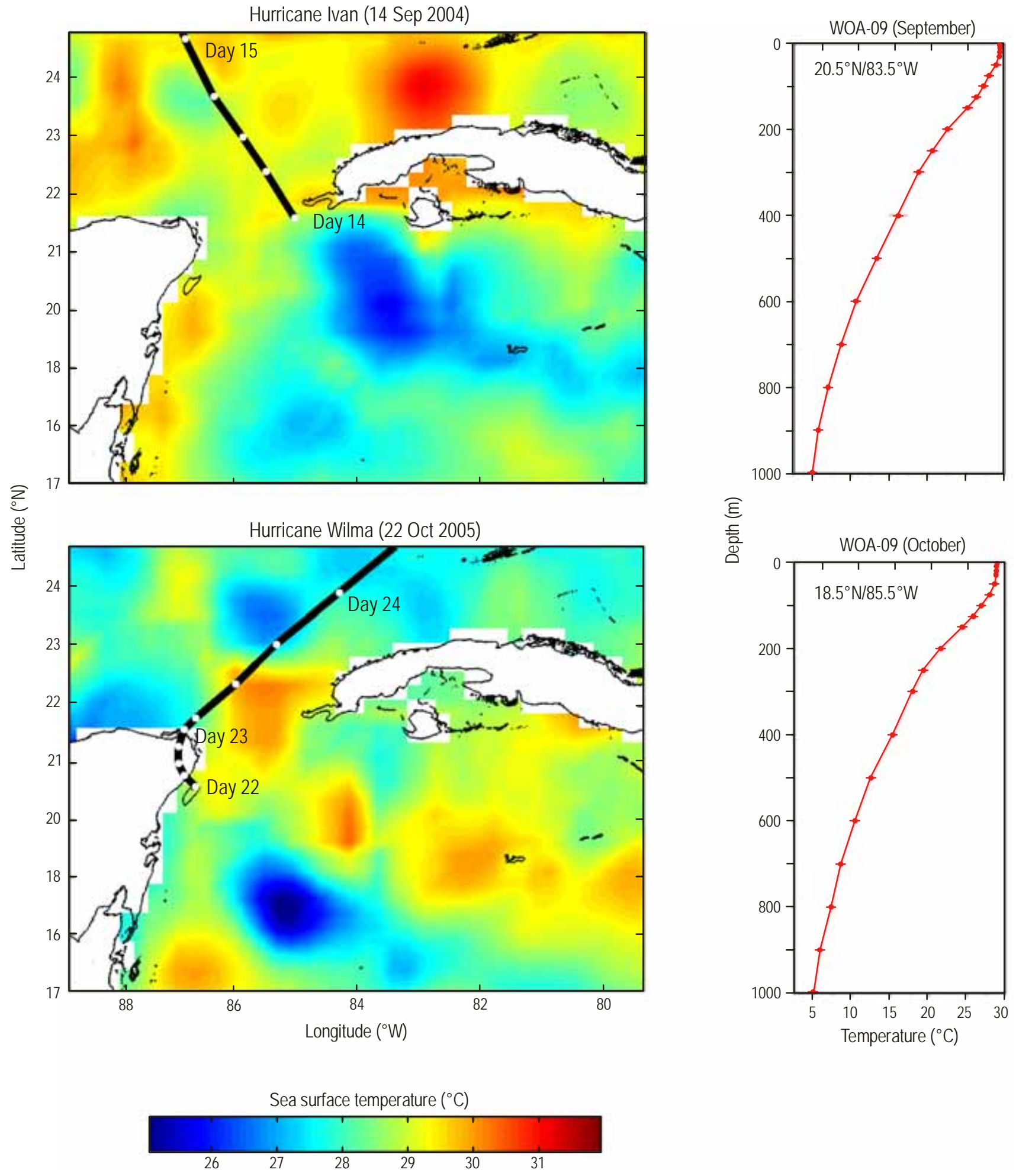

Supplement 2. (Left) Sea surface temperature during the passage (bold line) of hurricanes Ivan (September 2004) and Wilma (October 2005) through the Yucatan Basin. (Right) Monthly climatological temperature profiles at $20.5^{\circ} \mathrm{N} / 83.5^{\circ} \mathrm{W}$ during September and at $18.5^{\circ} \mathrm{N} / 85.5^{\circ} \mathrm{W}$ during October.

Suplemento 2. (Izquierda) Temperatura superficial del mar durante el paso (línea negra) de los huracanes Iván (septiembre de 2004) y Wilma (octubre de 2005) por la cuenca de Yucatán. (Derecha) Perfiles mensuales climatológicos de temperatura a $20.5^{\circ} \mathrm{N} / 83.5^{\circ} \mathrm{W}$ durante septiembre y a $18.5^{\circ} \mathrm{N} / 85.5^{\circ} \mathrm{W}$ durante octubre. 